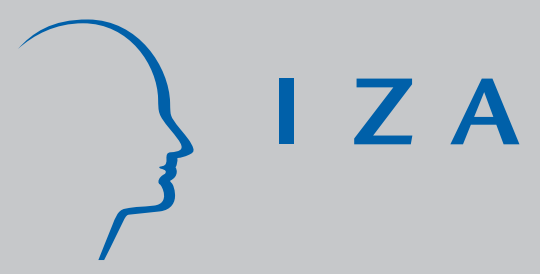

IZA DP No. 1470

J ob Turnover, Wage Rates, and Marital Stability: How Are They Related?

Avner Ahituv

Robert Lerman

J anuary 2005 


\title{
Job Turnover, Wage Rates, and Marital Stability: How Are They Related?
}

\author{
Avner Ahituv \\ University of Haifa and Urban Institute \\ Robert Lerman \\ American University, \\ Urban Institute and IZA Bonn
Discussion Paper No. 1470
January 2005

\author{
IZA \\ P.O. Box 7240 \\ 53072 Bonn \\ Germany \\ Phone: +49-228-3894-0 \\ Fax: +49-228-3894-180 \\ Email: iza@iza.org
}

\begin{abstract}
Any opinions expressed here are those of the author(s) and not those of the institute. Research disseminated by IZA may include views on policy, but the institute itself takes no institutional policy positions.

The Institute for the Study of Labor (IZA) in Bonn is a local and virtual international research center and a place of communication between science, politics and business. IZA is an independent nonprofit company supported by Deutsche Post World Net. The center is associated with the University of Bonn and offers a stimulating research environment through its research networks, research support, and visitors and doctoral programs. IZA engages in (i) original and internationally competitive research in all fields of labor economics, (ii) development of policy concepts, and (iii) dissemination of research results and concepts to the interested public.
\end{abstract}

IZA Discussion Papers often represent preliminary work and are circulated to encourage discussion. Citation of such a paper should account for its provisional character. A revised version may be available directly from the author. 
IZA Discussion Paper No. 1470

January 2005

\section{ABSTRACT \\ Job Turnover, Wage Rates, and Marital Stability: How Are They Related?*}

This study examines the interplay between job stability, wage rates, and marital instability. We use a Dynamic Selection Control model in which young men make sequential choices about work and family. Our empirical estimates derived from the model account for selfselection, simultaneity and unobserved heterogeneity. The results capture how job stability affects earnings, how both affect marital status, and how marital status affects earnings and job stability. The study reveals robust evidence that job instability lowers wages and the likelihood of getting and remaining married. At the same time, marriage raises wages and job stability. To project the sequential effects linking job stability, marital status, and earnings, we simulate the impacts of shocks that raise preferences for marriage and that increase education. Feedback effects cause the simulated wage gains from marriage to cumulate over time, indicating that long-run marriage wage premiums exceed conventional short-run estimates.

JEL Classification: $\quad \mathrm{C} 15, \mathrm{C} 33, \mathrm{~J} 12, \mathrm{~J} 31, \mathrm{~J} 63$

Keywords: marriage and marital dissolution, job turnover, wage rates, panel data

Corresponding author:

Robert I. Lerman

Urban Institute

2100 M Street, NW

Washington, DC 20037

USA

Email: blerman@ui.urban.org

\footnotetext{
* The authors gratefully acknowledge the financial support for this research provided by the National Institute for Child Health and Human Development. We also thank Henry Chen for excellent research assistance and the seminar participants in the European Summer Symposium in Labor Economics (ESSLE), European Association of Labor Economics (EALE), the University of Haifa and Tel-Aviv University for useful comments.
} 


\section{Introduction}

The trends toward later and shorter marriages have contributed greatly to the changing family patterns of the last half of the $20^{\text {th }}$ century (Wilson 2002). Not only are marriages lasting fewer years, the sources of marital dissolution have shifted dramatically from less widowhood to more divorce. Today, marital instability is common in most industrial countries but especially in the United States. In a recent cohort, 17 percent of men had separated or divorced by age $28 ;{ }^{1}$ by age 35, 20 percent of women had experienced a second divorce; and about 20 percent of marriages were dissolved during the first 5 years. One consequence of this instability is a high and rising rate of single parenthood. Between 1960 and 1996, the share of children not living with two parents more than tripled from 10 to over 30 percent. As of 1999, only about 60 percent of children lived with both biological and/or adoptive parents (Lerman 2001). The evidence is strong that growing up in one-parent families and unstable families is closely associated with long-term economic and social difficulties (Waite and Gallagher 2000; McLanahan and Sandefur 1994)

The high levels of marital instability in the U.S. have been taking place in the context of high levels of job instability. Every month, millions of workers leave one employer and take a job with another employer. It takes young workers a long time to enter a stable career and a long-term relationship with an employer. By the age of 30, high school graduates with no college have already worked for an average of eight employers. Nearly half of all male high school graduates experienced at least one spell of unemployment between ages 25-29 (U.S. Bureau of Labor Statistics 2000). Moreover, job instability is increasing among young men (Berhardt et al. 1998).

\footnotetext{
1 These tabulations come from the author's of the 1979 National Longitudinal Survey of Youth. In subsequent sections, we do not distinguish between separation and divorce, and use the terms divorce or dissolution.
} 
Researchers have long pointed to the potential connections between job market problems, marriage, and divorce. Wilson (1987) and others have tried to link the weakening of job market options for young men, especially young black men, to the decline in marriage rates. Recent increases in job instability (Neumark 2000; Berhardt et al. 1998; Light and McGarry 1998; and Farber 1995) might have led to negative consequences for workers and thus decreased their attractiveness as spouses. While the impact of unemployment on divorce has been studied for decades, important gaps remain. These gaps remain from both a substantive and methodological standpoint. Existing studies have typically focused on impacts running in a single direction—from a job market outcome to a marital status or vice versa. They often follow individuals through a specific transition, such as into marriage or out of marriage. In general, researchers have not yet extended their analyses to cover linkages between the long-term pathways in the job market and in marriage. As a result, existing approaches do not capture the time path of joint job-marriage decisions.

This study contributes to the existing literature by examining the connections between job instability, wages, and marital instability in a sequential framework. We analyze the entire sequence of annual job and marriage outcomes among young men by asking: 1) Do job stability and high wages promote marriage and marital stability? 2) How do marriage and marital stability affect job stability and wages? 3) How do shocks to education and initial labor market conditions affect the job market and marital status pathways of young men? To answer these questions, we develop a model in which young men make sequential choices about work and family and then estimate the model using a dynamic maximum likelihood (ML) approach that takes account of self-selection, simultaneity and heterogeneity into account.

The results shows that job instability contributes to reductions in wages and that high job turnover and low wages reduce the likelihood of getting and remaining married. In addition to 
identifying the causal link running from labor market outcomes to marital status, we find robust evidence that marriage leads to higher job stability and higher wage rates. The multivariate results reveal a pattern of dynamic feedbacks that imply cumulative impacts that exceed the contemporaneous impacts usually estimated in the literature. Simulations based on these findings illustrate how shocks that raise marriage or education or that reduce divorce set off virtuous cycles in which increased marriage interacts with increased job stability and earnings. The findings also suggest that previous studies understate the wage gains linked to marriage by ignoring the feedback effects on job stability and marriage duration.

This study improves our understanding of job and marital pathways and the linkages between them. It provides estimates of the effect of job instability on wages in the context of a model that accounts for changes in marital status. It captures the simultaneous impacts of job market factors on marriage and of marital status impacts on jobs and wages. Furthermore, it estimates these relationships while adjusting for unobserved heterogeneity that may affect both labor market and marital outcomes. Finally, it demonstrates how new econometric tools can estimate sequential job and marriage outcomes. Using these tools, one can project the long-term effects of marriage on job market outcomes and thus calculate a long-term marriage wage premium.

The next section reviews some of the relevant literature related to several lines of research relevant to this paper. Section III describes the data set, displays facts that motivate our study, and explains the rationale for the indicators we use to measure marital status and job stability. Section IV lays out and explains in detail the optimization model ascribed to individuals and how it connects to our empirical strategy. The multivariate results, which include both OLS estimates and those that control for unobserved heterogeneity, are presented in Section V. The simulation results in Section VI show examples of the implications of the statistical findings on the size of the feedback effects. Section VII concludes by discussing implications of our method and findings. 


\section{Studies Linking Job Stability, Wage Rates, and Marital Status}

Largely separate literatures have emerged on job stability and its determinants, marital stability and its determinants (Becker, Landes and Michael, 1977), and the interactions between labor market and marital status outcomes. In dealing with movement between jobs, economists frequently distinguish between unproductive turnover or churning and mobility that optimizes the worker-job match (Jovanovic, 1979; Mincer and Polachek, 1974). High turnover may represent an employer strategy to minimize labor costs by paying low wages and hiring or firing workers in response to short-term changes in demand. However, job mobility can be productive if job changes, including those involving unemployment, ultimately increase the efficiency of the employer-worker match. Both Topel and Ward (1992) and Klerman and Karoly (1994) find empirical evidence of the high concentration of job changes among youth. According to Topel and Ward, job mobility for young white men during the 1960s was so high that a typical worker would have held seven jobs during his first 10 years in the labor market, over two-thirds of his total career jobs. However, "rather than being wasteful and inefficient," Topel and Ward conclude that, "...high turnover among young workers may be critical to the development of stable work careers".

Other researchers do see turnover as wasteful. The informal U.S. system for integrating young people into careers may lead to unnecessarily high search costs and to a prolonged period in which young people are concentrated into jobs, which are characterized by high turnover, low wages, and little or no training (Hamilton, 1990). High rates of instability may, in turn, lower the marriage rates of young people. In a recent analysis, Neumark (2002) estimates the impact of early job stability on wages of young adult workers. Although Neumark provides an array of results, the key finding is that early job stability increases earnings, mostly by helping individuals maintain steady employment.

Many studies examine the effect of labor market outcomes on marital status. They typically 
use single equation models (often duration analysis) to examine how employment, unemployment, or wage levels affect marital or cohabitation status, or how marital/family status influences employment, unemployment, or wages. ${ }^{2}$ In a recent example of this literature, Oppenheimer (2003) examines the impacts of work experience, earnings, educational attainment, and other variables on two transitions of young men: 1) from non-cohabiting status to cohabitation or marriage; and 2) from never-married, cohabitation to marriage or separation. The results revealed varied roles for earnings, work experience, and education. Among non-cohabiters, very low earnings significantly reduced entries into marriage and high earnings and college diplomas significantly increased marriage rates. A recent study of the 1961 birth cohort of whites in Detroit by Xie, Raymo, Goyette, and Thornton (2003) examined whether an individual's earnings potential exerted different effects on entries into cohabitation versus entries into marriage. They used several earnings variables including current earnings, earnings over the subsequent five years, past earnings, and lifetime earnings. The authors found that higher earnings significantly increased the likelihood of entry into marriage but not into cohabitation. Past earnings showed the highest impact.

Charles and Stephens (2004) examine the effects of earnings disruptions on divorce. They use a probit analysis based on the Panel Survey of Income Dynamics to test whether layoffs, plant closings, and disability increase the likelihood of divorce in the year after the initial disruption takes place. In their analysis, layoffs or firings increase the risk of divorce, but plant closings and disability do not.

There is evidence that married men experienced a wage premium over unmarried men at least as far back as the nineteenth century (Goldin 1990). The recent wage premium literature focuses on whether the higher observed wage rates are the result of marriage itself or of unmeasured

\footnotetext{
2 See, for example, Manning and Smock (1995), Call and Teachman (1996), Presser (2000), Smock and Manning (1997), Teachman, Call, and Carver (1994), and Weiss and Willis (1997).
} 
characteristics that raise both wage rates and the likelihood of marriage. Using panel data, authors have estimated the effect of marriage using fixed effects models to control for unobserved heterogeneity. In one application of this technique examining the earnings of young white men from 1976 to 1980, Korenman and Newmark (1991) found that less than half of the 11 percent marriage premium is attributable to selection effects. Daniel's (1995) analysis of a more recent cohort of young men found similar overall effects, with slightly higher shares associated with selection. Following white men aged 19 to 29 in 1970 to 29 to 39 in 1980, Cornwell and Rupert (1997) estimated a marriage effect of about 5-7 percent on wages after controlling for observed characteristics and for fixed unobserved individual differences. Gray (1996) conducted a study examining two cohorts of 24-31 year-old white men using the same model. His results indicated that marriage gains fell sharply over time, largely due to the declining specialization of partners.

These studies of the impact of earnings on marital status rarely use a simultaneous framework that incorporates both directions of causation. Moreover, existing research does not account for the possibility that individual differences help explain stability both in marriage and jobs. After all, worker-employer and husband-wife relationships have common elements. Both involve working together in production. In each case, the two parties expect loyalty and responsibility from each other. When one party fails to live up to these expectations, the relationship often breaks down.

Chun and Lee (2001) exploit a simultaneous framework, using all 18-40 year-old working males from the March 1999 CPS. Their analysis employed a switching model in which the marriage equation is identified separately from the wage equation, using an index of the marriage market and the mother's country of birth—factors that should influence marriage but not wages. The estimates yielded a 12 percent average marriage effect on wages, but much larger effects ( 27 percent) among couples with wives who did not work in the job market. 
A second problem is that few existing studies follow individuals beyond a single transition. This can limit our understanding since job-marital outcomes at a point in time likely depend on the accumulation of past job and marital interactions. Rarely if ever do the studies capture the simultaneity between current and past job and marital outcomes. Finally, little research connects the role of early and continuing job market success with family formation and stability.

One exception is a recent paper by Gould (2003), which hypothesizes that men may invest in schooling and work in order to improve their marriage prospects. To test this hypothesis, he develops a model in which men maximize utility over marriage and earnings, where career choices in any period are neither working nor in school; being in school; working in a blue-collar job; or working in a white-collar job. The marriage outcomes include single; first, second, or third marriage with one of two types of wives (based on the goodness of the match); and first, second, or third divorce. Gould uses a structural approach to estimate his model. He finds that labor market decisions are strongly influenced by their returns in the marriage market, and suggest that researchers should not neglect this effect.

Like the Gould paper, our study extends the literature by examining the job and marital pathways of young men from the teenage years through the mid-30s. Unlike Gould, who emphasizes blue-collar and white-collar occupational choices, we focus on the link between job stability, wage rates, and marital status. Also, unlike Gould's use of a dynamic programming and simulation approach, our estimates come from a dynamic econometric model involving path dependent estimation and controls for unmeasured heterogeneity.

Our approach directly examines the success of men in the job market as both a cause and effect of marriage and marital stability. It is natural to extend the analysis to recognize possible path dependencies. Consider a positive economic shock that suddenly increases the number of good jobs in certain communities. Suppose that the higher quality jobs increase the number and/or stability of 
marriages. These changes may herald a sequence of positive, reinforcing outcomes; for example, the added marriages might plausibly raise wages and subsequently increase marital stability. On the other hand, the sequence may not be mutually reinforcing. The added marriages induced by more good jobs may be marginal and more subject to instability than marriages in communities that did not experience the initial gains in employment. If so, the pathways may involve fewer reinforcing positive linkages between jobs and marriages.

Our pathway analysis uses the Dynamic Selection Control model (Hotz et al., 2002) for estimating behavioral relationships involving simultaneous equations while controlling for potential selection bias. We estimate sequential equations for: 1) marital outcomes (single, married, divorced, remarried); 2) work/schooling and/or job stability; and 3) wage rates. Based on the estimated parameters, we are able to simulate the impact of shocks on the sequence of marital, job stability, and wage outcomes over time.

\section{The Data and Basic Tabulations}

\subsection{Data and Definitions}

The primary data source, the NLSY79, provides detailed data on respondents' family background, schooling and abilities, as well as extensive data on marital status, parenthood, and work histories, including the exact timing of marriages and job changes. Hence, the NLSY79 is an attractive data set for conducting this study. The NLSY79 is a national probability sample of 12,686 individuals (6,403 male) ages 14 to 21 as of January 1, 1979 who were re-interviewed annually until 1994 and semi-annually through 2004. This study uses only the data through 1994 to insure that annual information (in particular about job instability) is available for the joint analyses of job instability and marital stability.

Using the following adjustments, we select a sample well-suited to the analysis. First, 
because information about jobs held prior to 1978 is not always complete, we restrict the analyses to individuals who were aged 14 to 19 as of 1979 and thus exclude 1,772 cases aged 20-22 in 1979. For the younger cohort, we observe all jobs and family histories up to age 29-32. Second, because the NLSY has itself dropped some groups from follow-up interviews, we exclude those who were in the poor white oversample (521 cases) or in the military oversample (237 cases). Third, we exclude 366 cases because they completed less than 10 interviews (mostly because of nonresponses or attrition). This decision to limit the sample to men with at least ten years of sufficient data means a loss of less than 10 percent of the relevant cases. Fourth, given evidence of low or zero returns to work-whilein-high-school (Hotz et al. 2002) and given the fact that less than one percent of 17 year-old are married, we start following the careers and marital history of respondents from age 17 . We end up with a sample of 3,507 individuals, comprising 49,462 person-years, implying an average of more than 14 interviews per person.

Our analyses include three dependent variables that represent marital status, job stability, and wage rates. The NLSY records the exact date of changes in formal living arrangements (including marriages and births) and changes in informal arrangements such as cohabitation. Although the data allow for several definitions of family formation, we reviewed the data and chose to use the formal definition for single and married and a definition of divorce that includes separation. We found that most cohabitation leads to separation without children, while most marital separations lead to formal divorces.

The empirical model employs a multi-stage definition of continuation or change in marital status. Each individual in each year is classified as:

1) Singles who never married,

2) Those who married for the first time during this calendar year,

3) Those married in the current and also in the prior year (including second marriages), 
4) Those who divorced or separated during this year,

5) Those who were divorced or separated in the current and also in the prior year, or

6) Those who remarried during this calendar year

Using this classification, we estimate the effects of the observable variables and the unobservable factors on the transition rates from being single to first marriage, from marriage to divorce/separation, and from divorce/separation to remarriage. In equations predicting labor market outcomes, these marital status transitions appear as right hand side endogenous variables, thus yielding estimates of the labor market returns to each marital status.

The NLSY defines a job as an uninterrupted period of work with a particular employer. Transitions to and from jobs may involve labor force instability or job instability. Labor force instability involves frequent transitions from employment to schooling, unemployment, or nonparticipation, and then returning to employment (almost always to a different job). On the other hand, Job instability mainly involves changing employers. Focusing on labor force instability is more appropriate for ages 17-23 and for socioeconomic groups with low attachment to the labor force, while job instability is more appropriate for analyzing movements among men who are continuously employed during their adult years.

Our dependent variable, job change, incorporates both types of changes; the variable is set equal to zero if a man continues to work at the same job or remains not employed and equal to one if he changes jobs, labor force status or full-time schooling. We recognize the difficulty of a job change variable that combines movement between employers with changes in labor force status. However, this combination helps simplify the analysis without throwing away observations, and with modest costs. Most job changes occur because of moves from one employer to another without a change in labor force status. Though the job change dependent variable captures the change from one year to the next, we incorporate numbers of jobs as an independent variable in order to account 
for the effects resulting from changing jobs more than once per year. The effect of job changes may vary depending on whether the change is a result of a resignation, layoff, or termination. However, since information on the reason for job change is sometimes unreliable and is missing for over 30 percent of the observed job changes (see Appendix A), we do not incorporate this factor into the analysis. In any event, our main interest is in the long-term pathways; from this perspective, differences in the number of job changes may be more important than the reason for a specific job change.

There are tradeoffs in deciding how to treat job changes associated with leaving school. Incorporating school-leaving decisions as a separate dependent variable would unduly complicate a model mainly related to post-schooling changes. Using observations on individuals only after they leave school would involve disregarding many marital status and job changes that are of interest and are relevant to subsequent outcomes. Generally, we choose to account for job changes linked to leaving school by including enrollment status in the prior year as an independent variable. However, we also examine whether our results change when we include only observations of men after they leave school. ${ }^{3}$

The definition of the individual's wage rate is the natural log of the hourly rate of pay in the main job during the last calendar year. This indicator is appropriate, given our interest in capturing the effect of marital status and past work experiences on a worker's potential earnings. Using weekly or annual earnings would combine hourly pay with the amount of hours the respondent worked, aggravating endogenous bias.

\subsection{Descriptive Results}

This section familiarizes the reader with our data and motivates the formal analysis by presenting interesting facts about age patterns and correlations among marital status, earnings and

\footnotetext{
${ }^{3}$ Because these results yielded similar results to our main model, we do not report them, but they are available on request.
} 
work histories. Table 1 shows that the marriage differential is pronounced. No matter how we break the sample, married men have higher wages than single men. Interestingly, men in their first marriage have higher wages than those in their second marriage and divorced men have lower wages than married or remarried men. The differentials increase with age, are similar across race and ethnic groups and among men with different education backgrounds. The differentials involving annual wage growth are uneven, but follow the same pattern.

Table 2 replicates Table 7 from Topel and Ward (1992) and shows the differences in the wage levels and wage growth among men that kept the same job and men that changed their job during the last year. For each comparison, workers who stayed on the same job had higher wages than workers that changed jobs. On the other hand, annual wage growth was often higher among workers who changed jobs. The wage gap by job change increased with age, was higher among whites, but interestingly decreased with education. This combination of findings differs somewhat from the results of Topel and Ward (1992).

What might explain the differences between the patterns of wage levels and the patterns of wage growth? Among the possibilities are: (1) that the movers had relatively low wages in their former job and this is why they choose to quit (bad absolute match); (2) that job changes improve wages only for men who were unsuccessful with their former employer (bad relative match); (3) that employers offer wages above productivity to attract movers (and cut their wage growth later); and/or (4) that the new firm has less information about the poor productivity of these movers. In the first two cases, movers increase efficiency, while the other two explanations indicate market failures that cause firms to lose money.

The results presented in Table 3 show how labor market performance varies by marital status at age 28. In general, we find suggestive evidence for our hypotheses of relationships between job market performance and stable family status. Married men perform better than others in all the 
five categories. Moreover, this fact is also true for all the subgroups. Despite having more work experience than single men, separated or divorced men perform about the same as single men in terms of wages and weeks worked. Remarried men do better than the single, separated, and divorced groups, but less well than married men. To sum up, the table suggests a relationship between labor market performance and marriage. In subsequent sections, we pursue the analysis with an appropriate regression model that controls for observable differences and accounts for causality and self-selection issues.

Table 4 presents the age profile of the number of jobs by marital status and status changes. Starting at age 22, when most men are still single, men that have unstable married lives (two or more changes) also tend to change jobs more often. By age 25, a new phenomenon becomes visible with married men changing jobs less frequently than single men. The stability margins widen over time and by age 28 , married men have (on average) almost one fewer job than singles, and 1.7 fewer jobs than divorced men. Men in their second marriages have similar patterns to those of divorced men, but men with more than three marital changes show even more job changes.

At age 22, just over one in five men are married but by age 32, 56 percent are married and 44 percent are not married. This high share of 32 year-old men not in a married state is the result of two factors. Almost one-third are still single while others are moving in and out of marriage. The number of men with unstable marital lives is especially worrisome. By age 24,8 percent of the men have already divorced at least once, and by age 30, 3 percent have already divorced twice.

The descriptive tables suggest a positive relationship between job changes and marital status changes and a negative relationship between marital status changes and wage rates. We now turn to a formal model that structures how we examine the main forces, determinants, and casual effects behind these relationships. 


\section{The Framework and Empirical Strategy}

This section describes our conceptual framework and empirical strategy for estimating the simultaneous effects running between marital statuses, job changes and wage rates. We focus on explaining how the decision to marry or to dissolve a marriage is related to the decision to hold the present job or to move to a new job, and the consequence of these two decisions on wage rates. We present reasons for the expected size and direction of these complex interrelations and explain how we plan to identify and evaluate the various derivatives effects.

\subsection{Conceptual Framework}

The relationships between spouses and between employer and employees are similar in several respects. First, both are voluntary partnerships formed to improve production and consumption activities of both partners. Second, both involve investments in specific human capital to enhance marriages or jobs. Third, in both cases, the implicit contract is more important than the explicit contract (when they marry, couples agree to a lifetime union but often divorce; employees can often leave at will and employers bound by a formal contract often find ways to lay off or fire workers if circumstances warrant). One implication is that job changes or marital changes are likely to depend on the costs and benefits of the alternatives. Fourth, the duration of the partnerships varies enormously. Some partnerships last days, while others last a lifetime. Studies of the duration of jobs emphasize job-related factors, while relationship quality is the most important factor for the duration of a marital status. We explore how linkages between job and marital status durations might occur, either as a result of personal characteristics (an inclination for change or for stability) or external shocks.

There are obvious differences between job change and change in marital status. First, leaving a job is often a positive development, as when workers voluntarily take a better job well after completing any time commitment to an employer. In contrast, leaving a marriage almost always has 
highly unfavorable outcomes, especially since each spouse generally makes a lifetime commitment upon entering the marriage. Another way of putting this distinction is related to ex ante expectations. People might well take jobs expecting that they will ultimately obtain a better job elsewhere, while few people would choose to enter a marriage they believed would not last indefinitely. Perhaps as a result of these differences, average job tenure is shorter than the length of marriage.

Life events may link the two decisions. Moving from one labor market to another (say, to be close to parents and other relatives) is likely to change the job of at least one of the two spouses. A divorce caused by infidelity or a breakdown of the close relationships between spouses might cause a man to change his lifestyle, which in turn leads to job instability. Causation may run in the opposite direction as well. For example, losing a job causes several difficulties that may ultimately lead to dissolving a marriage.

We recognize that moving from one job to another and from one marital status to another involves more than one decision-maker. Employers may decide to lay off the individual; a potential spouse may refuse to marry or a spouse may initiate a divorce. However, we do not observe the choices made by employers or by women partners. Therefore, we emphasize the man's decision process, while recognizing that the decisions of others, uncertainty, misinformation, and other unobserved factors are likely to influence marriage and job met outcomes. Similarly, job change depends both on individual decisions to stay or to quit and employer decisions to keep or to fire a worker.

The strong relationship between changing jobs and wage growth is well-known and runs in both directions. Theoretically, job change can exert negative or positive effects on wages. Changing a job might result from "shopping" by workers for a better match and higher wage growth; alternatively, job change can sometime involve a loss of specific human capital, productivity, and wages. The expectation that workers will change jobs frequently can reduce the incentive of workers 
and firms to invest in human capital.

The effects of job stability and earnings on changes in marital status will depend on the specific marital transition-whether the change involves getting married or staying single, getting divorced or staying married, or getting remarried or staying divorced. Having high earnings or a stable job may increase a man's willingness to share income and his attractiveness to a potential spouse. While changing jobs increases the uncertainty of income flows, getting or staying married may increase the man's risk aversion and lead to less job change.

\subsection{Choices Involving Marital Status and Labor Market Outcomes}

Assume that a person marries when his expected utility from marriage exceeds the expected utility from remaining single (Becker, 1974) and separates when the expected utility in a married state falls below the expected utility in an unmarried state. Hence, he chooses between two options: to continue in his present marital status or to change that status (e.g., marry if single, separate if married, and so on). Accordingly, at age $t$, he chooses to change his family structure if

$$
F_{i t, k+1}(\text { change })>F_{i t, k} \text { (continue), }
$$

where $F_{i t t}$ denotes the expected lifetime value of individual $i$ who chooses one of the two alternatives at age $t$, given that he is presently at marital status $k$. The reward from choosing a marital state has two implicit components: (a) present utility and (b) the option value from choosing this state on the future streams of utilities. Among the factors expected to influence the individual's utility from marriage, divorce, or remarriage are labor market outcomes that include job change and wage levels. The way these and other factors influence the initial entry into a marriage will generally differ from the way they affect a marital dissolution or remarriage. To capture this element, our estimation approach allows different sets of parameters for each type of marital status change.

In addition to marital decisions, at age $t$ individual $i$ chooses whether to continue working for the same employer or to change his job. Following Topel and Ward (1992), an individual 
changes his job if

$$
V_{i t}\left(w^{o}, z, 0, M S\right)>V_{i t}(w, z, \tau, M S)
$$

where $V_{i t}$ denotes the expected lifetime value of individual $i$ at age $t, \mathrm{w}^{0}$ is an external wage offer, $\mathrm{w}$ is his present wage, $\mathrm{z}$ is total experience, $\tau$ denotes tenure in present job, and MS is his marital status. Note that the employment decision at age $t$ depends on external wage offers as well as previous employment and that the outcome of the male's present decision affects future employment and marital pathways.

\subsection{Estimation Strategy}

The empirical model is a modification of McFadden's (1984) Random Utility Model to dynamic discrete-choices and discrete-time. We let each period represent one year, designating $\mathrm{t}=0$ when the individual is 17 . As we discuss below, the econometric specification of the model draws on the Dynamic Selection Control method used in other applications by Cameron and Heckman (1998), Hotz et al. (2002), and Ahituv and Tienda (2004). This method estimates a representation of the decision rules (1) and (2).

For computation simplicity, we consider linear specifications of the $F_{i t t}$ 's and the $V_{i t}$ 's that depend on: (1) indicators of group membership and birth cohort, family background variables, AFQT, and local market conditions (X); (2) a vector of age-related variables measuring, at the beginning of each period, the accumulated amounts of schooling, children, work experience, and tenure in the present job $(Z)$; (3) the history of marital status changes (MS); and (4) a state-specific unobservable variable $(\varepsilon, \mu$ and $v)$. That is,

$$
F_{i t k}=X_{i t}^{F} \beta_{k}^{X}+Z_{i t-1}^{F} \beta_{k}^{Z}+\varepsilon_{i t k}
$$

and

$$
V_{i t}=X_{i t}^{V} \gamma^{x}+Z_{i t-1}^{V} \gamma^{Z}+M S_{i t}^{V} \gamma^{F}+\mu_{i t}
$$


where $\beta$ 's and $\gamma$ 's are vectors of parameters to be estimated for each equation ${ }^{4}$ and where the value and the coefficients of "to remain at the same state" are constrained to be zero. Note that the X`s and the $Z$ 's vary across equations (e.g. $\mathrm{X}^{\mathrm{F}} \neq \mathrm{X}^{\mathrm{V}}, \mathrm{Z}^{\mathrm{F}} \neq \mathrm{Z}^{\mathrm{W}}$ and so on).

Because we are interested in estimating the wage returns of earlier work experience, unstable job spells and marital instability, we also specify econometric representations of the wage processes, which we perceive as an outcome of the above two decisions. As with the value function above, the econometric representation of log-wages is linear. That is, the two discrete-choice equations are estimated jointly with a log-wage equation,

$$
W_{i t}=X_{i t}^{W} \delta^{x}+Z_{i t-1}^{W} \delta^{z}+M S_{i t}^{W} \delta^{F}+v_{i t},
$$

where $W_{i t}$ is the log of hourly wage adjusted for inflation. In this equation, we focus on the effects of job stability and marital status on wage rates.

Estimation of the parameters in (3)-(5), using the data on observed choices is complicated by several related problems of endogeneity and selection bias. For example, if the stochastic elements of the value functions (the $\varepsilon_{\mathrm{itj}}$ 's and $\mu_{i t}$ 's) are correlated over time (that would be the case if they contained person-specific, time-invariant components), the marital status variables $\left(F_{i t}\right)$ in $(3)$ and (4) will not be orthogonal to the $\varepsilon_{\mathrm{itj}}$ 's and the $\mu_{i t}$ 's. A second example is the case in which shocks that increase wage (the $v_{i j}$ 's) are correlated with the unobserved components of job turnover utilities (the $\mu_{i t}$ 's) (that would be the case of endogeneity). The above complications violate the orthogonality conditions between the independent variables and the stochastic elements.

To deal with such problems, we must account for the correlation structure of stochastic elements in the estimation of equations (3) to (5) and control for the correlation between these elements and our experience variables $\left(Z_{i t-1}\right.$ 's and $F_{i t-1}$ 's) at each age. Following the approach of Heckman and Singer (1984), and Hotz et al. (2002), we estimate the model using a conditional

\footnotetext{
${ }^{4}$ The coefficients across marital statuses $k=2,4,6$ are not constrained to be the same.
} 
maximum likelihood (ML) strategy in which the likelihood function is conditional on the estimated distribution of the unobserved individual factor.

\subsection{Dealing with Unobserved Heterogeneity and Simultaneous Bias}

We assume that the stochastic elements can be written as the following functions of a (common) person-specific stochastic component and idiosyncratic errors:

$$
\begin{aligned}
& \varepsilon_{i t k}=\alpha_{k}^{F} \xi_{i}+\omega_{i t k}^{F} \\
& \mu_{i t}=\alpha^{V} \xi_{i}+\omega_{i t}^{V}
\end{aligned}
$$

and

$$
v_{i t}=\alpha^{W} \xi_{i}+\omega_{i t}^{W}
$$

In this set of equations $\xi_{\mathrm{i}}$ denotes a person-specific disturbance (or factor), $\alpha_{\mathrm{j}}$ 's are specific factor loadings for marriage, work and wage, and $\omega_{\mathrm{isj}}$ 's denote idiosyncratic disturbance terms assumed uncorrelated with $\xi_{\mathrm{i}}$. Given the stochastic structure in (6)-(8), it follows that the $\varepsilon_{\text {isj }}$ 's and $\mu_{\text {isj }}$ 's will be correlated across time and across states, i.e.,

$$
\begin{aligned}
& \operatorname{Cov}\left(\varepsilon_{i t j}, \varepsilon_{i t} m\right)=\alpha_{j}^{F} \alpha_{m}^{F} \operatorname{Var}\left(\xi_{i}\right), \quad \text { for } t \neq t^{\prime}, j \neq m \\
& \operatorname{Cov}\left(\varepsilon_{i t j}, \mu_{i t^{\prime}}\right)=\alpha_{j}^{F} \alpha_{j}^{V} \operatorname{Var}\left(\xi_{i}\right), \quad \text { for } t \neq t^{\prime}, \text { and for all } j \\
& \operatorname{Cov}\left(\mu_{i t}, \mu_{i t^{\prime}}\right)=\alpha_{j}^{V} \alpha_{m}^{V} \operatorname{Var}\left(\xi_{i}\right), \quad \text { for } t \neq t^{\prime}, j \neq m .
\end{aligned}
$$

The above expressions indicate that the signs of the covariances between the $\varepsilon_{\mathrm{ijj}}$ 's and $\mu_{\mathrm{is}}$ 's are determined by the products of the corresponding factor loadings, a property we use to classify the factors representing unobserved heterogeneity. Given the stochastic structure in (6)-(8), the correlations between the $\varepsilon_{\text {isj }}$ 's and $v_{\mathrm{it}}$ 's, and between $v_{\mathrm{is}}$ 's and $\mu_{\mathrm{it}}$ 's will have similar properties. Hence, the distribution of $\xi_{\mathrm{i}}$ (the unobserved heterogeneity) is identified from the correlation of marital status, job choices and wages within and across time periods (and education stages) using maximum likelihood (ML) methods. Assuming that the idiosyncratic disturbance terms $\left(\omega_{\mathrm{is}}\right)$ are normally distributed with $\mathrm{E}(\omega)=0$, the finite distribution of $\xi$ is estimated non-parametrically 
(Heckman and Singer, 1984). Specifically, we use a four-point discrete distribution for $\xi$, and estimate the intermediate point as well as the probability mass at each point (the two extreme points are normalized to 0 and 1$)$.

Our estimates do not identify parameters of a structural microeconomic model, but they do represent causal impacts. Unlike IV techniques used elsewhere, the dynamic selection control model explicitly accounts for the endogeneity of past choices (see Hotz et al. (2002), page 229, for the advantages of this model over IV estimation). As Ichimura and Taber (2002) and Hotz et al. (2002) recently show, the nonparametric procedure that accounts for $\xi_{\text {i, }}$ combined with the dynamic selection structure of the model implies that $E\left(\omega_{i t}^{W} \mid X_{i t}^{W}, Z_{i t-1}^{W}, F_{i t}^{W}, \xi_{i}\right)=0$. The model accounts for all choices that lead to the present accumulation of labor market experiences and marital statuses at age $t$ as long as the initial condition assumption

$$
E\left(\xi_{i} \mid X_{i, 16}^{W}, Z_{i 16}^{W}, F_{i, 17}^{W},\right)=0
$$

holds. This assumption is plausible in our case because at age 16, less than one percent of youth have been married, and 89 percent are still in school. The panel data that we built allows us to model all subsequent work and family choices and thereby allows $\omega_{\mathrm{i}}$ to be uncorrelated with the experience variables at each subsequent age in the estimation of the model. Note that $\omega^{\mathrm{F}}$ and $\omega^{\mathrm{V}}$ will have similar properties to those of $\omega^{\mathrm{W}}$.

Finally, our model draws on good instruments to identify the causal effects of the interactions between wage rates, job stability, and marital status. We require instruments that affect one endogenous variable but have no direct effect on the others. As shown in Appendix Table B, many instruments are available. For example, county divorce rates and past frequency of religious attendance should affect marital status decisions, but have no direct impact on job turnover or earnings; county employment growth should affect job change but not directly affect marital status; 
county average earnings should influence earnings but not directly affect marital status. In addition, some family background characteristics and lagged variables also serve as instruments. Using a combination of these instruments can provide a reasonable exclusion strategy for the identification of the coefficients of interest, even if some of the instruments appear weak.

\section{Empirical Estimates of OLS and Dynamic Selection Models}

To ensure that our main conclusions are robust, we estimated several specifications. Some include respondents while they are in-school or in the military while others exclude them; some involve separate equations by race. Since the results were not sensitive to these differences in samples, we present findings for the full sample based on two models. Model 1 represents estimates of each equation separately, with OLS estimates of job change and earnings and probit estimates of the probabilities of entering marriage, divorce, or remarriage. Model 2 estimates the three equations jointly, controlling for unobserved heterogeneity and simultaneity as explained above.

The paper's focus is on the effect of job changes on wage rates and on the relationships running in both directions between marital status and labor market performance. The Model 2 estimates are intended to reveal the causal role of labor market success in determining marital outcomes as well as the causal impact of marriage, divorce, and remarriage on labor market outcomes. Table 5A displays the determinants of job change and earnings, while the effects of factors determining marital transitions appear in Table 5B.

\subsection{Determinants of Change in Jobs or Job Status}

Beginning with our central focus on the effects of marital status, we find clear and significant impacts. Job stability increases with a new marriage and a continuing marriage, but not with a remarriage. Newly divorced men tend to change jobs about as frequently as singles and the longer 
their spell of divorce, the more often they tend to change jobs. Somewhat surprisingly, controlling for unobserved heterogeneity has little effect on the values of these marital status coefficients. Thus, the positive relationship between marital stability and job stability is not the result of unobserved characteristics that increase both types of stability.

The effects of the control variables are interesting. Blacks are more likely to change jobs or job status than whites, but no significant differences emerged between Hispanics and whites. Higher AFQT scores, higher years of schooling, and higher parental income lower job change, apparently indicating that more advantaged young men are more likely to stay on the same job. Increasing age exerts a very small, but negative impact on job change. More years of work experience lower the probability of job change but the effect declines with additional years of experience. At 11 years of experience, job change starts increasing with additional experience. Still, in much of the range of this sample, changing jobs (or job status) decreases with experience. Military experience also lowers the probability of job change. Prior income reduces job change, while workers with many past job changes are more likely to change jobs in the coming year. Apparently, job history is important in determining job mobility in the future. Thus, a successful match between a worker and employer can have cumulative effects, raising job tenure and ultimately earnings. In contrast, time out of the labor force or changing many jobs has cumulative effects in the direction of low tenure.

On balance, favorable employment conditions apparently encourage job change. Higher employment growth in the respondent's county of residence and lower unemployment rates increase job change, indicating that when the aggregate demand for workers goes up, young workers take the opportunity to move to new jobs. Furthermore, urban residents change jobs more often, while those in counties with high average income are less likely to change jobs. Finally, added children seem to encourage men to change jobs. Having three or more children increases the probability of 
job change over other groups.

\subsection{Effects on Wage Rates}

The impacts of marital status on wage rates (Table 5A) are robust evidence of gains from marriage. New marriage, continuing marriage, and years of marriage all exert significant, positive impacts on wage rates both Models 1 and 2. A continuing marriage of five years is estimated to raise wages by 14 percent over single individuals. Unlike the job change results, divorced and separated men gain a statistically significant advantage over single men of about 4-6 percent. Still, the divorced group's wage advantage is less than half the advantage attained by married men. The impact of remarriage on wage rates is positive, significant, and substantial (about 10 percent). In contrast, remarriage exerted no discernible impact on job stability.

The preferred Model 2 specification demonstrates that the significant gains associated with marriage are not primarily due to simultaneity and heterogeneity. The gains to marriage and remarriage remain large and statistically significant, though the heterogeneity corrections slightly lower the projected impacts. The 14 percent gain from five years of marriage (and continuing marriage) is equivalent to the wage impact of nearly three years of increased schooling.

The wage gains linked to actual weeks of work experience vary widely. In all specifications, the returns to actual work experience are non-linear, with a positive coefficient on years of work experience and a negative coefficient on the square of years of work experience. According to the simultaneous specification in Table 5A, returns to work experience start out at 6.4 percent per year but they fall to zero after only 16 years. The age variable is positive and significant, but the agesquared term is negative enough to imply a slightly negative change in wages with increases in age beyond age 18 (holding work experience constant). Military experience conveys a positive return, but only in the Model 2 equations. Comparison between Models 1 and 2 on this variable suggests a negative selection into the military. The unadjusted results indicate military experience lowers 
wages, but once one controls for this selection effect in Model 2, each added year of military experience raises wages by nearly one-half of one percent.

The effects of job stability are robust and indicate wage gains from increases in job tenure at the same firm, from fewer jobs, and from job stability from one year to the next. On the basis of the results in Model 2, the decline in wage rates is about 2.8 percent from an additional four jobs and about 1.3 percent from changing jobs this year. Controls for unobserved heterogeneity matter, but they reduce the wage returns to job stability only modestly.

The results on the wage impact of job change are the reverse of the tabulations reported in Table 2. Apparently, the wage growth observed in Table 2 for job movers is not due to the new jobs, but to characteristics of these workers and/or to their work experience. The implications differ from those drawn by Topel and Ward (1992), which young men should search for better matches by changing jobs often. Our findings suggest that young men do not benefit from frequent changes in jobs.

The effects of the personal characteristics are similar to those found elsewhere, but sometimes vary with the specification. The wage coefficients are a negative 5.5 percent among blacks and a negative 1.4 percent among Hispanics in Model 2. Taking account of unobserved heterogeneity makes the picture for minorities worse than without the corrected indicators. The pattern is reversed for foreign-born workers. Their wage coefficient is negative in the Model 1 analysis, but becomes positive and significant with Model 2 and its correction for unobserved heterogeneity. High AFQT, high parental income, more schooling, urban residence, number of children, and healthy employment conditions raise wage outcomes in all specifications. In the preferred specification, the return to education is about 5 percent, a level similar to those found in other regressions that use AFQT as a control variable (Neumark, 2002). The estimated returns to schooling actually increase slightly when we control for unobserved heterogeneity. Having a GED 
lowers wage rates by 6 percent, holding school years constant. This effect emerges only when we account for heterogeneity.

Favorable labor market conditions raise wage rates significantly. A 1-percentage point increase in employment growth raises wage rates by 12 percent. Living in a high-income county and a county with a low unemployment rate also exerts significantly positive effects on wage rates.

\subsection{Marital Status Equations}

Our methodology resembles duration analysis in focusing on the transition from one marital status to another or to remaining in the initial status. However, it differs in that we follow men through each marital state and not simply from one status to another (e.g., single to married or from married to divorce). Hence, we estimate the effects of the observable variables and the unobservable factors on the exit-rates from single to married, from married to divorce, and from divorced to remarriage. In addition, we use the five marital status variables (relative to nevermarried) as endogenous determinants of labor market outcomes.

All the job market variables exert at least one significant impact on the distribution of marital status. Even holding constant for any of its negative earnings effects, job instability generally leads to negative marital outcomes. Changing jobs reduces the likelihood that single men will marry in the following year, raises the likelihood of divorce, and lowers the likelihood of remarriage. The total number of jobs has no significant effect on marriages or on remarriages but does raise the likelihood of divorce. Overall, these results suggest modest effects of job change on marriage, but large effects on divorce or separation.

High wages sharply increase the likelihood of men becoming and remaining married. The wage impacts are large and significant for entering marriage and for becoming divorced or separated. The effects on remarriage have a positive sign but the high standard errors suggest no statistically significant effect. Holding wages constant, work experience exerts a positive and significant effect 
on entering marriage but not on remaining married or remarrying.

Interestingly, the independent effects of education vary. Higher education has no effect on entry into marriage, but does lower rates of marital dissolution and raise rates of remarriage. One possible explanation for the absence of an education effect on entering marriage is that the increased desirability of an educated man is already reflected in higher wages; another is that remaining in school delays marriage, offsetting the likelihood that uneducated men are less attractive to women. Urban residents stay single longer, as do residents of counties with relative high income. However, neither variable exerts a significant effect on divorce or remarriage.

Differences in personal characteristics have a variety of effects. Blacks show a much lower connection to marriage than other groups, even after taking account of labor market outcomes, the county job market, age, work experience, and family background. In sharp contrast, the only effect of Hispanic background is to increase the likelihood of remarriage. The heterogeneity-adjusted results show a significant negative effect of AFQT scores on entering marriage and on divorce (holding education and wages constant). Apparently, youth with high-test scores enter marriage more slowly, but then divorce less frequently. Growing up in a female-headed family reduces entries into marriage, but has no significant impact on divorce or remarriage.

The religion variables show some surprising effects. Although, as expected, the frequency of religious attendance reduces entry into divorce or separation, it exerts no significant effect on marriage. Catholic status significantly lowers entry into marriage and into remarriage and exerted no significant effect on divorces.

\subsection{Analysis of Unobserved Common Factors}

This section discusses the importance and the robustness of the unobserved heterogeneity in Model 2. This model contains 10 free parameters more than Model 1 (5 coefficients of factorloading, 2 support-points and 3 mass probabilities). Panels $C$ and D in Table 5 presents the $\log$ of 
the likelihood functions of Models 1 and 2 and the locations of the four-support points and the estimated mass probabilities of Model 2. The likelihood-ratio test shows that Model 2 significantly improves the fit relative to Model 1, as the likelihood function increases by 5,225. It is not surprising, therefore, that the estimates of the support-points and mass probabilities are significant. Interestingly, the distributions of location of the support-points and mass probabilities are symmetric, which simplifies the convergence of the model.

The Model 2 estimates are especially important for the wage equations but less important for the marriage and remarriage equations. This is also the order of the significant level of the factor loading in each equation. About half of the coefficients in the wage equation changed significantly in moving from Model 1 to Model 2. Among the notable changes are declines in the wage premium for years married, which fall from $11 \%$ to $7 \%$, and in the premium for remarriage, which falls from $13 \%$ to $10 \%$. However, these marital status effects remain highly significant, indicating that the marriage premium is genuine. Model 2 also results in a notable increase in the return to education along with a more negative impact of GED (holding years of education constant). As noted above, the return to military experience becomes positive once we control for selection.

Turning to the interpretation of unobservable characteristics, the coefficients on the factor loadings in Tables $5 \mathrm{~A}$ and $5 \mathrm{~B}$ are positive in the job turnover, wage and divorce equations and negative in the marriage equation. This suggests that the unobserved components reflect men with the ability to command high wages, but are perhaps impatient and thus fall into bad job matches and bad matches linked to marriage. Applying the DSC model to our topic suggests that the fraction of this type of men in the population is not large.

\section{How Policy Interventions Affect Marriage and Job Pathways}

The findings from Model 2 allow us to simulate the impacts of shocks on marriage, job stability, and wages. The fact that marital status is both a cause and an effect of labor market 
outcomes suggests that feedbacks can play an important role in the pathways young people follow. The results show the possibility of virtuous circles_ - job stability leads to high wages, which lead to higher rates of marriage, which lead to more job stability and higher wages — and vicious circles with marital instability begetting job instability begetting more marital instability. The simulations complement the regression results by allowing clearer interpretation of the nonlinear observed effects on marital status and by quantifying the long-run effects of the dynamic interactions between marital status, wage rates, and job stability.

Before presenting the findings, it is important to recognize that marriage rates, job stability, and wage rates increase rapidly with age as people move through their 20 s and early 30 s. Thus, the impact of the shocks must be weighed against the original pathways. For that reason, we present the complete pathways of simulation 1, from age 17 to 32 for the five variables of interest in Appendix Table C. The base pathways are very similar to the original data. For the reader's convenience, we also present the base values in Table 6.

The first simulation in Table 6 is of a positive shock to the utility of the married state among never-married 25 year-olds. Suppose the interventions proposed by the Bush Administration to promote healthy marriages succeed in making marriage more appealing to 25 year-olds. Further suppose the effect of the program lasts only one year; after age 25, the utility functions return to their earlier parameters. Still, as a result of the single year change in the utility function of those at the margin of marrying, more 25 year-olds enter a first marriage. We then simulate how this change in marriage affects job stability, earnings, and subsequent marital in subsequent years through age 31. The direct effect of this intervention raises the share of 25 year-olds in first marriages by 7.2 percentage points. As predicted by Model 2 wage equation, the wage gain to each man who married because of the program is about 7.3 percent, leading to overall mean wage rate increases of 0.52 percent and job turnover decreases of 0.38 percent for all 25 year-olds. The subsequent impact of 
this higher wage rates is to decrease the likelihood of divorce. However, this feedback effect takes place alongside a general increase in the likelihood of marriage and divorce as people age. Thus, by age 31 , the difference across marital states narrows and only 3.3 percent are in a different marital status because of the initial shock (2.4 percent more are married and 0.9 percent more are divorced). Hence, the intervention assumed to affect marriage preferences in a single year both lowers the age at first marriage and modestly raises the proportion married six years later.

Still, the gains to earnings are impressive and persistent. As of ages 29-31, the group affected by the marriage initiative ends up with wage rates nearly 7 percent higher than they would have experienced without the program (over $95 \%$ of the initial gain). About two-thirds of this gain is due to the associated effects on wage rates from the higher rates of marriage and divorce at ages 29-31. One-third of the gain comes from the dynamic effects of marriage on wage rates and the feedback effects over time as well as the returns to the increased marital duration of the affected men.

The second experiment involves reducing the utility of divorce at age 25. As with the marriage simulation, the change in utility does not extend beyond 25 , though changes in marital status may persist. Initially, at age 25, the divorced proportion declines by 2.1 percentage points, fully offset by a 2.1 point increase in the proportion married. By ages $27-28$, the change in marital status (from the actual distribution) has declined nearly in half. In this case, as opposed to the first experiment, the immediate effect on job stability is stronger than the effect on wages. The average increase in earnings divided by those affected by the initial shocks to divorce stands at 7.6 percent as of ages 27 and 28, an amount similar to the effect of the first experiment. About 66 percent of this gain can be attributed to the lower divorce levels at 27-28. The remaining 34 percent is associated with the dynamic feedbacks linking lower divorce to higher job stability and earnings. Thus, reducing divorces (and increasing marriage) also has a feedback effect on wages, but lower than the 
shift that increases marriage.

The third experiment projects the effects of one year of additional schooling for all young men from ages 17 through 32. This change allows us to look at how a change in an exogenous variable creates interesting dynamic effects among of the endogenous variables. Model 2's estimate of the direct impact of one more year of schooling is a 5.03 increase in wage rates and a very small reduction in job change. Initially, the added education has virtually no effect on marriage and divorce. But over time, the education-induced added wages begin to increase marriage rates, which, in turn, raise wage rates further. The added education simulations, together with induced wage effects, leads to a rise in married proportion of 29-31 year-olds of about 1.7 percentage points and to a 1.2 percentage point decline in the share divorced. Through most of the period, the education and marital status changes lower job instability by about 1 percentage point in most years. The feedback effect involving the interaction of marital stability, job stability, and wage rates also adds to the wage gains induced by an initial increase in education. Thus, at the end of the period, wage rates are 5.38 percent higher than without the added school year or 0.35 percent more than the 5.03 percent gains that would take place without any feedback effects. Standard estimation procedures ignore this modest, but not trivial, additional return to education.

\section{Conclusions and Next Steps}

Job stability, wage rates, and marital stability are connected in complicated ways. A priori, leaving a job may take place for reasons positively or negatively related to marriage. An individual may leave a job because of the desire to move to another location and accommodate a new partner or spouse. On the other hand, moving jobs may put a strain on relationships, including marriage, and may lead to divorce or separation. Job stability might also be connected to marital status through its impact on wages. Here, too, there are many possibilities. Job stability may improve 
wage prospects or might limit opportunities that arise from switching positions. Finally, marriage may encourage job stability, just as it encourages stability in family relationships and in other behaviors (Waite and Gallagher, 2000). Thus, causation may run from job success to marital success or from marital success to job success.

This paper grapples with causation in an effort to understand the dynamic patterns of job change, earnings, and marital transitions. Using data covering a cohort of young men as they age from 18 through 32, the analysis yields some robust findings about causation and dynamics.

Overall, the results show clear connections between marital stability, job stability, and wage rates. First, changing jobs and having a large number of jobs end up lowering wage rates and reducing marriage rates. The finding that job instability lowers wages runs contrary to the conclusions of Topel and Ward (1992). Although differences in samples and time periods might explain differences in results, a more compelling explanation is the fact that our model is more complete, incorporates marital stability simultaneously, and uses adjustments for heterogeneity.

A second key finding is that marriage enhances job stability and raises wage rates. The results show that the observed marriage effects are not the result of reverse causation; they are significant even after taking account of the fact that job stability and higher wage rates increase the likelihood of marriage. The presence of a marriage premium in the context of adjustments for heterogeneity and simultaneity is a strong signal that projects that promote healthy marriages might indirectly improve job market outcomes as well. The results suggest a "virtuous cycle" set off either by an increased propensity to marry or by increased stability of jobs. For example, a higher propensity to marry would improve job prospects and job stability, which, in turn, would increase the duration of marriages.

The simulations reveal the quantitative dimensions of feedback effects of shocks in the form of marriage promotion and added schooling. A one-year rise in the utility from marriage at age 25 
speeds the entry into marriage, which in turn, raises earnings over the next several years. In any event, the effects on marriages dissipate as people age and marry. However, the induced gain in wage rates remains significant largely because of the feedback effect of early marriage on job stability and wage rates. Added education raises wage rates immediately and increases marriage rates of men by their early 30s, but the marriage-induced feedback effects on wage rates are modest. Similarly, the shock causing less divorce at age 25 exerts a short-term and intermediate term impact, but the effects dissipate over time.

One reason for pursuing questions about job change and marital instability is that both may generate externalities. Workers changing jobs to gain a higher wage do not account for the possibility that their behavior will reduce an employer's willingness to invest in the human capital of all other workers. Parents may be unable to calculate the fact that remaining single or getting a divorce may reduce earnings and lead to a reduction in child welfare (Becker, 1974).

A second rationale is to understand the potential role of marriage policies in reducing poverty and inequality, especially among families with children. The evidence suggests that prior estimates of the marriage premium may understate the long-term gains from marriage and the dynamic effects that take place partly as a result of marriage effects on job stability, wage effects on marriage, and subsequent feedback effects on wage rates. Thus, a combined job and marriage initiative might help the country reach antipoverty goals by reinforcing the changes along one dimension (say, work) and ultimately lead to a stable family life and, in turn, a higher income (Haskins and Sawhill 2003). 


\section{References}

Ahituv, Aver and Marta Tienda. 2004 "Employment Activity, Motherhood and School Continuation Decisions of Young White, Black and Hispanic Women.” Journal of Labor Economics, 22(1). 115-158.

Becker, Gary S. 1974. "A Theory of Marriage," In Economics of the Family, edited by T.W. Schultz, Chicago University Press, Chicago.

Becker, Gary S., Elisabeth Landes, and Robert Michael . 1977 "An Economic Analysis of Marital Instability,” Journal of Political Economy, 1141-1187.

Bernhardt, Annette, Martina Morris, Marc Handcock, and Marc Scott. 1998. Trends in Job Instability and Wages for Young Adult Men, Institute on Education and the Economy no. IEEE Working Paper 8. New York, New York: Teachers College, Columbia University.

Cameron, Steven and James Heckman. 1998. "Life Cycle Schooling and Dynamic Selection Bias: Models and Evidence for Five Cohorts of American Males." Journal of Political Economy, 106, 262-333.

Call, Vaughn, and Jay Teachman. 1996. "Life-Course Timing and Sequencing of Marriage and Military Service and Their Effects on Marital Stability." Journal of Marriage and the Family, 58. February. 219-26.

Charles, Kofi and Melvin Stephens, Jr. 2004. "Job Displacement, Disability, and Divorce." Journal of Labor Economics. Vol. 22 (2). 489-522.

Cornwell, Christopher, and Peter Rupert. 1997. Unobservable individual effects, marriage, and the earnings of young men. Economic Inquiry, 35 (April): 285-94.

Chun, Hyunbae and Injae Lee. 2001. 'Why Do Married Men Earn More: Productivity or Marriage Selection?” Economic Inquiry. Vol. 39 (2). April. 307-19.

Daniel, Kermit. 1995. The marriage premium. In The New Economics of Human Behavior, edited by Mariano Tommasi and Kathryn Ierulli, 113-25. Cambridge, England: Cambridge University Press.

Farber, Henry. 1995. Are Lifetime Jobs Disappearing? Job Duration in the United States, 1973-1993, National Bureau of Economic Research no. Working Paper 5014. Cambridge, Massachusetts.

Goldin, Claudia. 1990. Understanding the Gender Gap: An Economic History of American Women. New York: Oxford University Press.

Gould, D. Eric. 2003. "Marriage and Career: The Dynamic Decisions of Young Men," The Hebrew University of Jerusalem. Unpublished manuscript. 
Gray, Jeffrey S. 1996. The fall in men's return to marriage: Declining productivity effects or changing selection? Journal of Human Resources, 32, no. 3: 481-504.

Hamilton, Stephen. 1990. Apprenticeship for Adulthood: Preparing Youth for the Future. New York, New York: The Free Press.

Haskins, Ron and Isabel Sawhill. 2003. Work and Marriage: The Way to End Poverty and Welfare. Welfare Reform and Beyond, \#28. Washington, DC: Brookings Institution.

Heckman, James J., and B. Singer. 1984. "A Method for Minimizing the Impact of Distributional Assumptions in Econometric Models of Duration Analysis." Econometrica 52:217-320.

Hotz, V. Joseph, Lixin Xu, Marta Tienda and Avner Ahituv. 2002 “Are There Returns to the Wages of Young Men from Working While in School?" Review of Economics and Statistics, 84(1). (May): 221-236.

Ichimura, Hidehiko and Christopher Taber. 2002. "Semiparametric Reduced-Form Estimation of Tuition Subsidies.” American Economic Review. May. 286-92.

Jovanovic, Boyan. 1979. "Job Matching and the Theory of Turnover." Journal of Political Economy, 87(5): 972-990.

Klerman, Jacob Alex, and Lynn A. Karoly. 1994. "Young Men and the Transition to Stable Employment." Monthly Labor Review, 117, no. 8, August: 31-48.

Korenman, Sanders, and David Neumark. 1991. Does marriage really make men more productive? Journal of Human Resources, 26: 282-307.

Lerman, Robert. 2001. "Marriage As A Protective Force Against Economic Hardship.” The Urban Institute.

Light, Audrey and Kathleen McGarry, 1998. "Job Change Patterns and the Wages of Young Men.” Review of Economics and Statistics. Vol. 80 (2). p 276-86. May.

Manning, Wendy D., and Pamela Smock. 1995. "Why Marry? Race and the Transition to Marriage Among Cohabitors." Demography, 32, no. 4, November: 509-20.

McFadden, Daniel L. 1984. "Econometric Analysis of Qualitative Response Models.” In Handbook of Econometrics. Volume II. Griliches, Zvi and Intriligator, Michael D. (ed.), North-Holland, New York. 1396-1457

McLanahan, Sara, and Gary D. Sandefur. 1994. Growing up with a single parent: What hurts, what helps. Cambridge: Harvard University Press.

Mincer, Jacob and Solomon Polachek. 1974. "Family Investments in Human Capital: Earnings of Women."Journal of Political Economy (March/April): S76-S108.

Neumark, David. 2000. Changes in Job Stability and Job Security: A Collective Effort to Untangle, Reconcile, and Interpret the Evidence, National Bureau of Economic Research. Working 
Paper 7472. Cambridge, Massachusetts.

Neumark, David, 2002 "Youth Labor Markets in the United States: Shopping Around or Staying Put," The Review of Economics and Statistics, 84(3): August, 462-482.

Oppenheimer, Valerie. 2003. "Cohabiting and Marriage During Young Men's Career Development Process." Demography. February. 127-149.

Osterman, Paul. 1980. Getting Started: The Youth Labor Market. Cambridge, Massachusetts: MIT Press.

Presser, Harriet. 2000. "Nonstandard Work Schedules and Marital Instability." Journal of Marriage and the Family, 62 (February): 93-110.

Smock, Pamela J. and Wendy D. Manning. 1997. “Cohabitation Partners' Economic Circumstances and Marriage.” Demography, Vol 34, 3:331-341.

Teachman, J.D., V.R.A. Call, and K.P. Carver. 1994. Marital Status and the Duration of Joblessness Among White Men. Journal of Marriage and the Family. Vol. 56, 415-428.

Topel, Robert H. and Michael P. Ward. 1992. "Job Mobility and the Careers of Young Men." Quarterly Journal of Economics, 196:339-479.

U.S. Bureau of Labor Statistics. 2000. Number of Jobs Held, Labor Market Activity, and Earnings Growth Over Two Decades: Results from a Longitudinal Survey. Washington, DC.

Waite, Linda J. and Maggie Gallagher. 2000. The case for marriage. New York: Doubleday.

Weiss, Yoram and Robert J. Willis. 1997. "Match Quality, New Information, and Marital Dissolution.” Journal of Labor Economics. Vol 15, 1:S293-S329.

Wilson, James Q. 2002. The Marriage Problem. New York: Harper Collins.

Wilson, William J. 1987. The Truly Disadvantaged. Chicago: University of Chicago Press.

Xie, Yu, James M. Raymo, Kimberly Goyette, and Arland Thornton. 2003. "Economic Potential and Entry Into Marriage and Cohabitation." Demography. February. 351-368. 
Table 1: Hourly Rate of Pay and Wage Growth by Marital Statuses

Panel A: full sample at certain ages

\begin{tabular}{lccccccccc}
\hline \hline & \multicolumn{4}{c}{ Hourly Rate of Pay } & & \multicolumn{4}{c}{ Annual Wage Growth } \\
\cline { 2 - 3 } Age & Single & Married & Divorced & $\begin{array}{c}\text { Re- } \\
\text { Married }\end{array}$ & & Single & Married & Divorced & $\begin{array}{c}\text { Re- } \\
\text { Married }\end{array}$ \\
\hline 19 & 4.6 & 5.3 & NA & NA & & $5.8 \%$ & $10.8 \%$ & NA & NA \\
23 & 6.2 & 7.1 & 6.3 & NA & & $10.1 \%$ & $12.3 \%$ & NA & NA \\
27 & 7.6 & 8.9 & 6.9 & 8.5 & & $2.7 \%$ & $4.1 \%$ & $-1.0 \%$ & $9.4 \%$ \\
31 & 7.6 & 9.7 & 7.2 & 8.8 & & $2.6 \%$ & $2.8 \%$ & $1.0 \%$ & $7.1 \%$ \\
Number of Obs. & 6,184 & 3,149 & 758 & 343 & & 6,184 & 3,149 & 758 & 343 \\
\hline
\end{tabular}

Panel B: by race and ethnic groups, age 28-30

\begin{tabular}{lccccccccc}
\hline \hline & \multicolumn{4}{c}{ Hourly Rate of Pay } & & \multicolumn{4}{c}{ Annual Wage Growth } \\
\cline { 2 - 3 } Group & Single & Married & Divorced & $\begin{array}{c}\text { Re- } \\
\text { Married }\end{array}$ & & Single & Married & Divorced & $\begin{array}{c}\text { Re- } \\
\text { Married }\end{array}$ \\
\hline Hispanic & 7.6 & 8.7 & 7.2 & 7.6 & & $0.6 \%$ & $2.3 \%$ & $0.7 \%$ & $1.0 \%$ \\
Black & 6.5 & 7.9 & 6.4 & 7.4 & & $-0.4 \%$ & $-1.2 \%$ & $-0.7 \%$ & $4.4 \%$ \\
White & 8.7 & 9.8 & 8.9 & 8.3 & & $3.2 \%$ & $2.1 \%$ & $2.8 \%$ & $2.1 \%$ \\
Number of Obs. & 3,219 & 3,781 & 1,084 & 574 & & 3,219 & 3,781 & 1,084 & 574 \\
\hline
\end{tabular}

Panel C: by education groups, age 28-30

\begin{tabular}{lccccccccc}
\hline \hline & \multicolumn{4}{c}{ Hourly Rate of Pay } & & \multicolumn{4}{c}{ Annual Wage Growth } \\
\cline { 2 - 3 } Group & Single & Married & Divorced & $\begin{array}{c}\text { Re- } \\
\text { Married }\end{array}$ & & Single & Married & Divorced & $\begin{array}{c}\text { Re- } \\
\text { Married }\end{array}$ \\
\hline Less than HS & 5.6 & 6.8 & 6.8 & 6.8 & & $-3.4 \%$ & $-3.0 \%$ & $-1.9 \%$ & $0.4 \%$ \\
HS & 6.8 & 8.3 & 7.3 & 7.6 & & $1.1 \%$ & $2.0 \%$ & $0.8 \%$ & $1.4 \%$ \\
Some College & 8.4 & 9.6 & 9.9 & 9.6 & & $3.1 \%$ & $0.6 \%$ & $8.5 \%$ & $5.4 \%$ \\
BA and more & 10.4 & 12.0 & 10.3 & 9.8 & & $4.1 \%$ & $4.2 \%$ & $-1.1 \%$ & $6.1 \%$ \\
Number of Obs. & 3,219 & 3,781 & 1,084 & 574 & & 3,219 & 3,781 & 1,084 & 574 \\
\hline
\end{tabular}


Table 2: Hourly Rate of Pay and Wage Growth by Job Transaction Status

Panel A: full sample at certain ages

\begin{tabular}{lccccc}
\hline \hline & \multicolumn{2}{c}{ Hourly Rate of Pay } & & \multicolumn{2}{c}{ Annual Wage Growth } \\
\cline { 2 - 3 } \cline { 6 - 7 } Age & Same Job & New Job & & Same Job & New Job \\
\hline 19 & 4.8 & 4.6 & & $4.2 \%$ & $7.3 \%$ \\
23 & 6.7 & 6.2 & & $7.7 \%$ & $14.2 \%$ \\
27 & 8.6 & 7.1 & & $2.8 \%$ & $4.1 \%$ \\
31 & 9.2 & 6.9 & & $2.7 \%$ & $3.2 \%$ \\
Number of Obs. & 5,860 & 4,574 & & 5,860 & 4,574 \\
\hline
\end{tabular}

Panel B: by race and ethnic groups, age 28

\begin{tabular}{lccccc}
\hline \hline \multirow{2}{*}{ Group } & \multicolumn{2}{c}{ Hourly Rate of Pay } & & \multicolumn{2}{c}{ Annual Wage Growth } \\
\cline { 2 - 3 } \cline { 6 - 6 } Hispanic & Same Job & New Job & & Same Job & New Job \\
Black & 8.2 & 7.6 & & $-2.0 \%$ & $8.7 \%$ \\
White & 7.3 & 6.5 & & $0.8 \%$ & $-7.1 \%$ \\
Number of Obs. & 2,083 & 8.2 & & $3.3 \%$ & $7.5 \%$ \\
\hline
\end{tabular}

Panel C: by education groups, age 28

\begin{tabular}{lccccc}
\hline \hline \multirow{2}{*}{ Group } & \multicolumn{2}{c}{ Hourly Rate of Pay } & & \multicolumn{2}{c}{ Annual Wage Growth } \\
\cline { 2 - 3 } \cline { 6 - 6 } Less than HS & Same Job & New Job & & Same Job & New Job \\
HS & 6.8 & 5.9 & & $-4.8 \%$ & $2.1 \%$ \\
Some College & 9.0 & 8.9 & & $3.1 \%$ & $3.3 \%$ \\
BA and more & 11.0 & 10.9 & & $4.4 \%$ & $8.3 \%$ \\
Number of Obs. & 2,083 & 951 & & 2,083 & 951 \\
\hline
\end{tabular}


Table 3: Indicators of Labor Market Performance by Family Status at Age 28

Panel A: Percent keeping the same job over last calendar year

\begin{tabular}{lccccc}
\hline \hline Family Status & All & Blacks & Whites & HS & $\begin{array}{c}\text { BA and } \\
\text { more }\end{array}$ \\
\hline Single & $56 \%$ & $48 \%$ & $65 \%$ & $56 \%$ & $61 \%$ \\
Married & $71 \%$ & $65 \%$ & $73 \%$ & $71 \%$ & $74 \%$ \\
Separated or Divorced & $50 \%$ & $39 \%$ & $55 \%$ & $52 \%$ & $39 \%$ \\
Re-Married & $60 \%$ & $55 \%$ & $62 \%$ & $62 \%$ & $73 \%$ \\
\hline
\end{tabular}

Panel B: Cumulative number of jobs

\begin{tabular}{lccccc}
\hline \hline Family Status & All & Blacks & Whites & HS & $\begin{array}{c}\text { BA and } \\
\text { more }\end{array}$ \\
\hline Single & 8.8 & 8.1 & 9.4 & 8.5 & 8.9 \\
Married & 8.0 & 7.7 & 8.0 & 7.4 & 8.1 \\
Separated or Divorced & 9.6 & 8.8 & 10.1 & 9.5 & 9.1 \\
Re-Married & 9.8 & 7.9 & 10.1 & 9.6 & 13.0 \\
\hline
\end{tabular}

Panel C: Weeks work last calendar year

\begin{tabular}{lccccc}
\hline \hline Family Status & All & Blacks & Whites & HS & $\begin{array}{c}\text { BA and } \\
\text { more }\end{array}$ \\
\hline Single & 39.5 & 35.0 & 44.3 & 38.2 & 45.4 \\
Married & 45.1 & 42.0 & 46.0 & 44.1 & 48.1 \\
Separated or Divorced & 39.1 & 35.9 & 42.9 & 39.7 & 47.5 \\
Re-Married & 43.1 & 37.2 & 44.1 & 43.4 & 42.0 \\
\hline
\end{tabular}

Panel D: Cumulative weeks of work experience

\begin{tabular}{lccccc}
\hline \hline Family Status & All & Blacks & Whites & HS & $\begin{array}{c}\text { BA and } \\
\text { more }\end{array}$ \\
\hline Single & 358 & 314 & 405 & 355 & 384 \\
Married & 426 & 375 & 442 & 429 & 421 \\
Separated or Divorced & 381 & 346 & 410 & 389 & 415 \\
Re-Married & 425 & 341 & 443 & 436 & 375 \\
\hline
\end{tabular}

Panel E: Hourly rate of pay

\begin{tabular}{lccccc}
\hline \hline Family Status & All & Blacks & Whites & HS & $\begin{array}{c}\text { BA and } \\
\text { more }\end{array}$ \\
\hline Single & 7.7 & 6.8 & 8.5 & 6.9 & 10.5 \\
Married & 9.0 & 7.5 & 9.5 & 8.1 & 11.5 \\
Separated or Divorced & 7.3 & 6.6 & 8.1 & 7.6 & 9.3 \\
Re-Married & 8.2 & 7.3 & 8.4 & 7.7 & NA \\
& & & & & \\
Number of Obs. & 3,428 & 1,050 & 1,707 & 1,610 & 568 \\
\hline
\end{tabular}


Table 4: Number of Jobs by Age and by Marital Statuses

\begin{tabular}{|c|c|c|c|c|c|}
\hline Age & $\begin{array}{c}\text { Single, Never } \\
\text { Married }\end{array}$ & First Marriage & $\begin{array}{c}\text { First Separation } \\
\text { (2 Changes) }\end{array}$ & $\begin{array}{c}\text { Second Marriage } \\
\text { (3 Changes) }\end{array}$ & $\begin{array}{c}\text { Four or More } \\
\text { Marital Changes }\end{array}$ \\
\hline 22 & $\begin{array}{c}5.2 \\
(75 \%)\end{array}$ & $\begin{array}{c}5.3 \\
(21 \%)\end{array}$ & $\begin{array}{c}6.3 \\
(3 \%)\end{array}$ & $\begin{array}{c}7.1 \\
(1 \%)\end{array}$ & $\begin{array}{c}8.3 \\
(0 \%)\end{array}$ \\
\hline 23 & $\begin{array}{c}5.9 \\
(67 \%)\end{array}$ & $\begin{array}{c}5.9 \\
(27 \%)\end{array}$ & $\begin{array}{c}6.8 \\
(5 \%)\end{array}$ & $\begin{array}{c}6.8 \\
(1 \%)\end{array}$ & $\begin{array}{l}11.8 \\
(0 \%)\end{array}$ \\
\hline 24 & $\begin{array}{c}6.6 \\
(61 \%)\end{array}$ & $\begin{array}{c}6.4 \\
(31 \%)\end{array}$ & $\begin{array}{c}7.4 \\
(6 \%)\end{array}$ & $\begin{array}{c}8.2 \\
(2 \%)\end{array}$ & $\begin{array}{l}11.1 \\
(0 \%)\end{array}$ \\
\hline 25 & $\begin{array}{c}7.2 \\
(54 \%)\end{array}$ & $\begin{array}{c}6.9 \\
(36 \%)\end{array}$ & $\begin{array}{c}8.1 \\
(7 \%)\end{array}$ & $\begin{array}{c}8.1 \\
(2 \%)\end{array}$ & $\begin{array}{l}11.3 \\
(1 \%)\end{array}$ \\
\hline 26 & $\begin{array}{c}7.8 \\
(49 \%)\end{array}$ & $\begin{array}{c}7.3 \\
(39 \%)\end{array}$ & $\begin{array}{c}8.6 \\
(8 \%)\end{array}$ & $\begin{array}{c}8.7 \\
(3 \%)\end{array}$ & $\begin{array}{l}10.6 \\
(1 \%)\end{array}$ \\
\hline 27 & $\begin{array}{c}8.4 \\
(45 \%)\end{array}$ & $\begin{array}{c}7.7 \\
(40 \%)\end{array}$ & $\begin{array}{c}9.1 \\
(10 \%)\end{array}$ & $\begin{array}{c}9.4 \\
(4 \%)\end{array}$ & $\begin{array}{l}11.1 \\
(1 \%)\end{array}$ \\
\hline 28 & $\begin{array}{c}8.9 \\
(41 \%)\end{array}$ & $\begin{array}{c}8.0 \\
(41 \%)\end{array}$ & $\begin{array}{c}9.7 \\
(11 \%)\end{array}$ & $\begin{array}{c}9.4 \\
(5 \%)\end{array}$ & $\begin{array}{l}11.3 \\
(2 \%)\end{array}$ \\
\hline 29 & $\begin{array}{c}9.3 \\
(38 \%)\end{array}$ & $\begin{array}{c}8.4 \\
(43 \%)\end{array}$ & $\begin{array}{c}10.0 \\
(11 \%)\end{array}$ & $\begin{array}{l}10.0 \\
(6 \%)\end{array}$ & $\begin{array}{l}11.5 \\
(2 \%)\end{array}$ \\
\hline 30 & $\begin{array}{c}9.7 \\
(35 \%)\end{array}$ & $\begin{array}{c}8.5 \\
(43 \%)\end{array}$ & $\begin{array}{c}10.3 \\
(11 \%)\end{array}$ & $\begin{array}{l}10.3 \\
(7 \%)\end{array}$ & $\begin{array}{l}11.4 \\
(3 \%)\end{array}$ \\
\hline 31 & $\begin{array}{c}9.8 \\
(32 \%)\end{array}$ & $\begin{array}{c}8.6 \\
(45 \%)\end{array}$ & $\begin{array}{c}10.5 \\
(12 \%)\end{array}$ & $\begin{array}{c}9.7 \\
(7 \%)\end{array}$ & $\begin{array}{l}11.9 \\
(3 \%)\end{array}$ \\
\hline 32 & $\begin{array}{c}9.9 \\
(30 \%)\end{array}$ & $\begin{array}{c}8.7 \\
(46 \%)\end{array}$ & $\begin{array}{c}10.2 \\
(12 \%)\end{array}$ & $\begin{array}{c}9.2 \\
(8 \%)\end{array}$ & $\begin{array}{l}11.4 \\
(3 \%)\end{array}$ \\
\hline
\end{tabular}

Notes: The share of people in each marital status for each age is in parentheses 
Table 5A: Determinants of Job Stability and Wage Rates, Simultaneous Models

\begin{tabular}{|c|c|c|c|c|}
\hline & \multicolumn{2}{|c|}{ Job Change } & \multicolumn{2}{|c|}{ Ln Hourly Wages } \\
\hline & Model 1 & Model 2 & Model 1 & Model 2 \\
\hline Factor Loading & & $\begin{array}{c}0.0402^{* * *} \\
(0.0111)\end{array}$ & & $\begin{array}{l}1.4025^{* * *} \\
(0.0084)\end{array}$ \\
\hline Constant & $\begin{array}{c}0.7795^{* * *} \\
(0.0879)\end{array}$ & $\begin{array}{c}1.7637 * * * \\
(0.0702)\end{array}$ & $\begin{array}{c}0.4321 * * * \\
(0.0982)\end{array}$ & $\begin{array}{c}-0.3850^{* * *} \\
(0.0680)\end{array}$ \\
\hline Age & $\begin{array}{l}-0.0004 \\
(0.0074)\end{array}$ & $\begin{array}{l}-0.0007 \\
(0.0058)\end{array}$ & $\begin{array}{c}0.0296^{* * *} \\
(0.0083)\end{array}$ & $\begin{array}{c}0.0237 * * * \\
(0.0055)\end{array}$ \\
\hline Age Squared & $\begin{array}{l}0.0003^{*} \\
(0.0001)\end{array}$ & $\begin{array}{c}0.0003^{* *} \\
(0.0001)\end{array}$ & $\begin{array}{c}-0.0009 * * * \\
(0.0002)\end{array}$ & $\begin{array}{c}-0.0007^{* * *} \\
(0.0001)\end{array}$ \\
\hline Black & $\begin{array}{c}0.0208^{* * *} \\
(0.0054)\end{array}$ & $\begin{array}{c}0.0202^{* * *} \\
(0.0041)\end{array}$ & $\begin{array}{c}-0.0372 * * * \\
(0.0061)\end{array}$ & $\begin{array}{c}-0.0545^{* * *} \\
(0.0059)\end{array}$ \\
\hline Hispanic & $\begin{array}{l}-0.0068 \\
(0.0060)\end{array}$ & $\begin{array}{c}-0.0074 * \\
(0.0044)\end{array}$ & $\begin{array}{c}0.0165^{* *} \\
(0.0070)\end{array}$ & $\begin{array}{c}-0.0144 * * \\
(0.0070)\end{array}$ \\
\hline Foreign Born & & & $\begin{array}{l}-0.0086 \\
(0.0092)\end{array}$ & $\begin{array}{c}0.0221 * * \\
(0.0094)\end{array}$ \\
\hline AFQT & $\begin{array}{c}-0.0087 * * * \\
(0.0012)\end{array}$ & $\begin{array}{c}-0.0088^{* * *} \\
(0.0010)\end{array}$ & $\begin{array}{c}0.0175^{* * *} \\
(0.0014)\end{array}$ & $\begin{array}{c}0.0104 * * * \\
(0.0013)\end{array}$ \\
\hline Family Income, 1979 & $\begin{array}{c}-0.2929 * * \\
(0.1364)\end{array}$ & $\begin{array}{c}-0.2633^{* *} \\
(0.1060)\end{array}$ & $\begin{array}{c}1.9289 \text { *** } \\
(0.1533)\end{array}$ & $\begin{array}{c}2.1326^{* * * *} \\
(0.1367)\end{array}$ \\
\hline Missing Family Income & $\begin{array}{l}-0.0028 \\
(0.0057)\end{array}$ & $\begin{array}{l}-0.0015 \\
(0.0042)\end{array}$ & $\begin{array}{c}0.0687 * * * \\
(0.0064)\end{array}$ & $\begin{array}{c}0.0878^{* * * *} \\
(0.0062)\end{array}$ \\
\hline Mother's Education & $\begin{array}{c}0.0007 \\
(0.0008)\end{array}$ & $\begin{array}{c}0.0006 \\
(0.0006)\end{array}$ & $\begin{array}{l}-0.0002 \\
(0.0009)\end{array}$ & $\begin{array}{c}-0.0034 * * * \\
(0.0009)\end{array}$ \\
\hline Work Experience & $\begin{array}{c}-0.1382^{* * *} \\
(0.0025)\end{array}$ & $\begin{array}{c}-0.1377 * * * \\
(0.0017)\end{array}$ & $\begin{array}{c}0.0668^{* * *} \\
(0.0029)\end{array}$ & $\begin{array}{c}0.0637^{* * *} \\
(0.0020)\end{array}$ \\
\hline Experience squared & $\begin{array}{c}0.0056^{* * *} \\
0.0002)\end{array}$ & $\begin{array}{c}0.0056^{* * *} \\
(0.0001)\end{array}$ & $\begin{array}{c}-0.0019 * * * \\
(0.0002)\end{array}$ & $\begin{array}{c}-0.0019 * * * \\
(0.0001)\end{array}$ \\
\hline Military experience & $\begin{array}{c}-0.0382^{* * *} \\
(0.0012)\end{array}$ & $\begin{array}{c}-0.0380^{* * *} \\
(0.0007)\end{array}$ & $\begin{array}{c}-0.0092^{* * * *} \\
(0.0013)\end{array}$ & $\begin{array}{c}0.0044 * * * \\
(0.0008)\end{array}$ \\
\hline Number of Jobs & $\begin{array}{c}0.0344 * * * \\
(0.0005)\end{array}$ & $\begin{array}{c}0.0344^{* * *} \\
(0.0003)\end{array}$ & $\begin{array}{c}-0.0083^{* * *} \\
(0.0006)\end{array}$ & $\begin{array}{c}-0.0070^{* * *} \\
(0.0005)\end{array}$ \\
\hline Job change prior year & & & $\begin{array}{c}-0.0183^{* * *} \\
(0.0052)\end{array}$ & $\begin{array}{c}-0.0127^{* *} \\
(0.0049)\end{array}$ \\
\hline Ln wage prior year & $\begin{array}{c}-0.0414 * * * \\
(0.0040)\end{array}$ & $\begin{array}{c}-0.0491 * * * \\
(0.0045)\end{array}$ & & \\
\hline
\end{tabular}


Table 5A (Continued)

\begin{tabular}{|c|c|c|c|c|}
\hline & \multicolumn{2}{|c|}{ Job Change } & \multicolumn{2}{|c|}{ Ln Hourly Wages } \\
\hline & Model 1 & Model 2 & Model 1 & Model 2 \\
\hline Years Married & $\begin{array}{l}-0.0016 \\
(0.0015)\end{array}$ & $\begin{array}{l}-0.0016 \\
(0.0012)\end{array}$ & $\begin{array}{c}0.0111 * * * \\
(0.0017)\end{array}$ & $\begin{array}{c}0.0074 * * * \\
(0.0012)\end{array}$ \\
\hline New Marriage & $\begin{array}{c}-0.0500 * * * \\
(0.0094)\end{array}$ & $\begin{array}{c}-0.0498^{* * *} \\
(0.0091)\end{array}$ & $\begin{array}{c}0.0749 * * * \\
(0.0106)\end{array}$ & $\begin{array}{c}0.0660^{* * *} \\
(0.0117)\end{array}$ \\
\hline Continuing Marriage & $\begin{array}{c}-0.0643^{* * *} \\
(0.0090)\end{array}$ & $\begin{array}{c}-0.0634 * * * \\
(0.0074)\end{array}$ & $\begin{array}{c}0.0968^{* * *} \\
(0.0101)\end{array}$ & $\begin{array}{c}0.1031 * * * \\
(0.0080)\end{array}$ \\
\hline $\begin{array}{l}\text { New Divorce or } \\
\text { Separation }\end{array}$ & $\begin{array}{c}0.0183 \\
(0.0147)\end{array}$ & $\begin{array}{c}0.0187 \\
(0.0143)\end{array}$ & $\begin{array}{c}0.0646 * * * \\
(0.0166)\end{array}$ & $\begin{array}{l}0.0560^{* *} \\
(0.0200)\end{array}$ \\
\hline $\begin{array}{l}\text { Continuing } \\
\text { Divorce/Separation }\end{array}$ & $\begin{array}{c}0.0147 \\
(0.0099)\end{array}$ & $\begin{array}{c}0.0149 * * \\
(0.0072)\end{array}$ & $\begin{array}{c}0.0496^{* * *} \\
(0.0111)\end{array}$ & $\begin{array}{c}0.0438^{* * *} \\
(0.0085)\end{array}$ \\
\hline New Remarriage & $\begin{array}{l}-0.0092 \\
(0.0218)\end{array}$ & $\begin{array}{l}-0.0094 \\
(0.0222)\end{array}$ & $\begin{array}{c}0.1328^{* * *} \\
(0.0245)\end{array}$ & $\begin{array}{c}0.1027 * * * \\
(0.0257)\end{array}$ \\
\hline One or two children & $\begin{array}{c}0.0149 * * * \\
(0.0055)\end{array}$ & $\begin{array}{c}0.0144 * * * \\
(0.0040)\end{array}$ & $\begin{array}{l}0.0122^{*} \\
(0.0063)\end{array}$ & $\begin{array}{l}-0.0049 \\
(0.0046)\end{array}$ \\
\hline Three or more children & $\begin{array}{c}0.0304 * * * \\
(0.0096)\end{array}$ & $\begin{array}{c}0.0295^{* * *} \\
(0.0066)\end{array}$ & $\begin{array}{c}-0.0655^{* * *} \\
(0.0108)\end{array}$ & $\begin{array}{c}-0.0752^{* * *} \\
(0.0075)\end{array}$ \\
\hline Highest Grade Completed & $\begin{array}{c}-0.0102^{* * *} \\
(0.0012)\end{array}$ & $\begin{array}{c}-0.0096^{* * *} \\
(0.0009)\end{array}$ & $\begin{array}{c}0.0387 * * * \\
(0.0014)\end{array}$ & $\begin{array}{c}0.0502^{* * *} \\
(0.0010)\end{array}$ \\
\hline In School & & & $\begin{array}{c}-0.1496 * * * \\
(0.0065)\end{array}$ & $\begin{array}{c}-0.1292^{* * *} \\
(0.0047)\end{array}$ \\
\hline In School prior year & $\begin{array}{c}0.1120 * * * \\
(0.0060)\end{array}$ & $\begin{array}{c}0.1114 * * * \\
(0.0050)\end{array}$ & & \\
\hline GED Level & & & $\begin{array}{l}-0.0014 \\
(0.0080)\end{array}$ & $\begin{array}{c}-0.0531 * * * \\
(0.0063)\end{array}$ \\
\hline Residence in Urban Area & $\begin{array}{l}0.0107 * * \\
(0.0052)\end{array}$ & $\begin{array}{l}0.0109 * * \\
(0.0039)\end{array}$ & $\begin{array}{c}0.0487 * * * \\
(0.0061)\end{array}$ & $\begin{array}{c}0.0314 * * * \\
(0.0048)\end{array}$ \\
\hline County Average Earnings & & & $\begin{array}{c}0.0191 * * * \\
(0.0006)\end{array}$ & $\begin{array}{c}0.0177 * * * \\
(0.0004)\end{array}$ \\
\hline $\begin{array}{l}\text { County employment } \\
\text { growth }\end{array}$ & $\begin{array}{c}0.0873 * * * \\
(0.0245)\end{array}$ & $\begin{array}{c}0.0855^{* * *} \\
(0.0252)\end{array}$ & $\begin{array}{c}0.2095^{* * *} \\
(0.0277)\end{array}$ & $\begin{array}{c}0.1198^{* * *} \\
(0.0249)\end{array}$ \\
\hline $\begin{array}{l}\text { County Unemployment } \\
\text { Rate }\end{array}$ & $\begin{array}{l}-0.0010^{*} \\
(0.0006)\end{array}$ & $\begin{array}{c}-0.0011 * * \\
(.0005)\end{array}$ & $\begin{array}{c}-0.0025^{* * *} \\
(0.0007)\end{array}$ & $\begin{array}{r}-.0026 * * * \\
(0.0006)\end{array}$ \\
\hline
\end{tabular}

Notes: Detailed description of the variables are in Table Apeendix B. 
Table 5B: Determinants of Marital Status Transitions, Simultaneous Models

\begin{tabular}{|c|c|c|c|c|c|c|}
\hline & \multicolumn{2}{|c|}{ Entry into marriage } & \multicolumn{2}{|c|}{$\begin{array}{c}\text { Entry into } \\
\text { divorce/separation }\end{array}$} & \multicolumn{2}{|c|}{ Entry into remarriage } \\
\hline & Model 1 & Model 2 & Model 1 & Model 2 & Model 1 & Model 2 \\
\hline Factor Loading & & $\begin{array}{l}-0.1094 \\
(0.0869)\end{array}$ & & $\begin{array}{l}0.2346^{*} \\
(0.1335)\end{array}$ & & $\begin{array}{r}0.2288 \\
(0.2380)\end{array}$ \\
\hline Constant & $\begin{array}{c}-7.9120^{* * *} \\
(0.5777)\end{array}$ & $\begin{array}{c}-8.8261 * * * \\
(0.5610)\end{array}$ & $\begin{array}{l}-0.6279 \\
(1.1671)\end{array}$ & $\begin{array}{l}-0.9369 \\
(1.2590)\end{array}$ & $\begin{array}{l}-2.9588 \\
(2.5631)\end{array}$ & $\begin{array}{l}-3.2180 \\
(2.8130)\end{array}$ \\
\hline Age & $\begin{array}{c}0.5302^{* * *} \\
(0.0489)\end{array}$ & $\begin{array}{c}0.6128^{* * *} \\
(0.0474)\end{array}$ & $\begin{array}{l}0.0191 \\
(0.0922)\end{array}$ & $\begin{array}{c}0.0355 \\
(0.0998)\end{array}$ & $\begin{array}{c}0.1466 \\
(0.1939)\end{array}$ & $\begin{array}{c}0.1588 \\
(0.2127)\end{array}$ \\
\hline Age Squared & $\begin{array}{c}-0.0107 * * * \\
(0.0010)\end{array}$ & $\begin{array}{c}-0.0124 * * * \\
(0.0010)\end{array}$ & $\begin{array}{l}-0.0011 \\
(0.0018)\end{array}$ & $\begin{array}{l}-0.0014 \\
(0.0019)\end{array}$ & $\begin{array}{l}-0.0038 \\
(0.0036)\end{array}$ & $\begin{array}{l}-0.0041 \\
(0.0039)\end{array}$ \\
\hline Black & $\begin{array}{c}-0.3257 * * * \\
(0.0347)\end{array}$ & $\begin{array}{c}-0.3415^{* * *} \\
(0.0338)\end{array}$ & $\begin{array}{c}0.3005^{* * *} \\
(0.0545)\end{array}$ & $\begin{array}{c}0.2864 * * * \\
(0.0509)\end{array}$ & $\begin{array}{c}-0.2103 * * \\
(0.0897)\end{array}$ & $\begin{array}{c}-0.2126 * * \\
(0.0968)\end{array}$ \\
\hline Hispanic & $\begin{array}{l}0.0120 \\
(0.0377)\end{array}$ & $\begin{array}{c}0.0308 \\
(0.0360)\end{array}$ & $\begin{array}{l}0.0147 \\
(0.0584)\end{array}$ & $\begin{array}{l}-0.0008 \\
(0.0566)\end{array}$ & $\begin{array}{c}0.2198^{* *} \\
(0.1020)\end{array}$ & $\begin{array}{c}0.2171 * * \\
(0.0978)\end{array}$ \\
\hline AFQT & $\begin{array}{l}-0.0078 \\
(0.0068)\end{array}$ & $\begin{array}{l}-0.0100^{*} \\
(0.0067)\end{array}$ & $\begin{array}{l}-0.0164 \\
(0.0114)\end{array}$ & $\begin{array}{l}-0.0168^{*} \\
(0.0113)\end{array}$ & $\begin{array}{l}-0.0050 \\
(0.0203)\end{array}$ & $\begin{array}{l}-0.0048 \\
(0.0212)\end{array}$ \\
\hline Family Income, 1979 & $\begin{array}{l}-1.2256 \\
(0.7930)\end{array}$ & $\begin{array}{l}-1.0732 \\
(0.8390)\end{array}$ & $\begin{array}{l}-0.6914 \\
(1.4691)\end{array}$ & $\begin{array}{l}-0.9825 \\
(1.4496)\end{array}$ & $\begin{array}{l}-1.2356 \\
(2.7431)\end{array}$ & $\begin{array}{l}-0.7811 \\
(3.0163)\end{array}$ \\
\hline Missing Family Income & $\begin{array}{l}0.0174 \\
(0.0341)\end{array}$ & $\begin{array}{c}0.0691 * * \\
(0.0327)\end{array}$ & $\begin{array}{l}0.0442 \\
(0.0526)\end{array}$ & $\begin{array}{c}0.0541 \\
(0.0497)\end{array}$ & $\begin{array}{c}0.0420 \\
(0.0895)\end{array}$ & $\begin{array}{c}0.0529 \\
(0.0926)\end{array}$ \\
\hline Mother's Education & $\begin{array}{c}-0.0099 * * \\
(0.0047)\end{array}$ & $\begin{array}{c}-0.0113^{* *} \\
(0.0046)\end{array}$ & $\begin{array}{l}0.0049 \\
(0.0077)\end{array}$ & $\begin{array}{c}0.0058 \\
(0.0074)\end{array}$ & $\begin{array}{c}0.0153 \\
(0.0133)\end{array}$ & $\begin{array}{c}0.0136 \\
(0.0130)\end{array}$ \\
\hline Siblings & $\begin{array}{c}0.0046 \\
(0.0047)\end{array}$ & $\begin{array}{c}0.0032 \\
(0.0047)\end{array}$ & $\begin{array}{c}-0.0290^{* * *} \\
(0.0077)\end{array}$ & $\begin{array}{c}-0.0280^{* * *} \\
(0.0072)\end{array}$ & $\begin{array}{c}0.0004 \\
(0.0131)\end{array}$ & $\begin{array}{l}-0.0002 \\
(0.0136)\end{array}$ \\
\hline $\begin{array}{l}\text { Female Headed } \\
\text { Household }\end{array}$ & $\begin{array}{c}-0.0774 * * \\
(0.0315)\end{array}$ & $\begin{array}{c}-0.0631 * * \\
(0.0303)\end{array}$ & $\begin{array}{l}0.0123 \\
(0.0507)\end{array}$ & $\begin{array}{c}0.0136 \\
(0.0485)\end{array}$ & $\begin{array}{l}-0.0207 \\
(0.0838)\end{array}$ & $\begin{array}{l}-0.0183 \\
(0.0870)\end{array}$ \\
\hline Work Experience & $\begin{array}{c}0.0492^{* * *} \\
(0.0152)\end{array}$ & $\begin{array}{c}0.0382^{* *} \\
(0.0162)\end{array}$ & $\begin{array}{l}-0.0042 \\
(0.0219)\end{array}$ & $\begin{array}{l}-0.0023 \\
(0.0234)\end{array}$ & $\begin{array}{c}0.0132 \\
(0.0391)\end{array}$ & $\begin{array}{c}0.0133 \\
(0.0423)\end{array}$ \\
\hline Experience squared & $\begin{array}{l}-0.0011 \\
(0.0012)\end{array}$ & $\begin{array}{l}-0.0003 \\
(0.0013)\end{array}$ & $\begin{array}{l}-0.0006 \\
(0.0015)\end{array}$ & $\begin{array}{l}-0.0007 \\
(0.0016)\end{array}$ & $\begin{array}{c}0.0006 \\
(0.0026)\end{array}$ & $\begin{array}{c}0.0006 \\
(0.0028)\end{array}$ \\
\hline Number of jobs & $\begin{array}{c}0.0029 \\
(0.0033)\end{array}$ & $\begin{array}{c}0.0040 \\
(0.0033)\end{array}$ & $\begin{array}{c}0.0199 * * * \\
(0.0042)\end{array}$ & $\begin{array}{c}0.0204 * * * \\
(0.0044)\end{array}$ & $\begin{array}{c}0.0017 \\
(0.0064)\end{array}$ & $\begin{array}{c}0.0019 \\
(0.0067)\end{array}$ \\
\hline Job change prior year & $\begin{array}{c}-0.0691 * * * \\
(0.0253)\end{array}$ & $\begin{array}{c}-0.0847 * * * \\
(0.0255)\end{array}$ & $\begin{array}{c}0.1019 * * \\
(0.0403)\end{array}$ & $\begin{array}{c}0.1162^{* *} \\
(0.0437)\end{array}$ & $\begin{array}{c}-0.1207^{*} \\
(0.0671)\end{array}$ & $\begin{array}{c}-0.1262 * \\
(0.0709)\end{array}$ \\
\hline Ln wage prior year & $\begin{array}{c}0.1733^{* * *} \\
(0.0225)\end{array}$ & $\begin{array}{c}0.1994 * * * \\
(0.0322)\end{array}$ & $\begin{array}{c}-0.1054 * * * \\
(0.0378)\end{array}$ & $\begin{array}{c}-0.1655^{* *} \\
(0.0574)\end{array}$ & $\begin{array}{c}0.0859 \\
(0.0648)\end{array}$ & $\begin{array}{c}0.0368 \\
(0.0881)\end{array}$ \\
\hline
\end{tabular}


Table 5B (Continued)

\begin{tabular}{lcccccc}
\hline \hline & \multicolumn{2}{c}{ Entry into marriage } & \multicolumn{2}{c}{$\begin{array}{c}\text { Entry into } \\
\text { divorce/separation }\end{array}$} & \multicolumn{2}{c}{ Entry into remarriage } \\
\cline { 2 - 7 } & Model 1 & Model 2 & Model 1 & Model 2 & Model 1 & Model 2 \\
\hline Highest Grade & -0.0016 & -0.0035 & $-0.0499 * * *$ & $-0.0486^{* * *}$ & $0.0467^{* *}$ & $0.0498^{* *}$ \\
Completed & $(0.0067)$ & $(0.0067)$ & $(0.0109)$ & $(0.0111)$ & $(0.0201)$ & $(0.0221)$ \\
Baptist Religion & 0.0098 & 0.0198 & 0.0468 & 0.0518 & $0.1352^{*}$ & $0.1371 *$ \\
& $(0.0311)$ & $(0.0305)$ & $(0.0468)$ & $(0.0435)$ & $(0.0769)$ & $(0.0813)$ \\
Catholic Religion & $-0.0774^{* *}$ & $-0.0784^{* *}$ & 0.0194 & 0.0195 & $-0.2359^{* *}$ & $-0.2339^{* *}$ \\
& $(0.0303)$ & $(0.0300)$ & $(0.0494)$ & $(0.0492)$ & $(0.0900)$ & $(0.0881)$ \\
Frequency of Church & $0.0128^{*}$ & 0.0095 & $-0.0268^{* *}$ & $-0.0271 * *$ & -0.0027 & -0.0014 \\
Attendance, 1979 & $(0.0068)$ & $(0.0067)$ & $(0.0107)$ & $(0.0103)$ & $(0.0182)$ & $(0.0190)$ \\
Residence in Urban & $-0.1320^{* * *}$ & $-0.1359^{* * *}$ & 0.0733 & 0.0616 & 0.0465 & 0.0429 \\
Area & $(0.0316)$ & $(0.0309)$ & $(0.0490)$ & $(0.0465)$ & $(0.0838)$ & $(0.0843)$ \\
County Average & $-0.0111^{* * *}$ & $-0.0117^{* * *}$ & 0.0031 & 0.0037 & -0.0078 & -0.0068 \\
Earnings & $(0.0030)$ & $(0.0029)$ & $(0.0047)$ & $(0.0046)$ & $(0.0079)$ & $(0.0078)$ \\
County Divorce Rate & $0.0328^{* * *}$ & $0.0325^{* * *}$ & 0.0169 & $0.0165^{*}$ & -0.0004 & -0.0006 \\
& $(0.0071)$ & $(0.0069)$ & $(0.0113)$ & $(0.0108)$ & $(0.0179)$ & $(0.0187)$ \\
\hline
\end{tabular}

Table 5C: Estimates of Common Unobserved Factors Model 2

\begin{tabular}{llll}
\hline \hline Support Point 1 & 0.0000 & Prob Mass for Pt 1 & $\begin{array}{l}0.0214^{* * *} \\
(0.0029)\end{array}$ \\
Support Point 2 & $\begin{array}{l}0.4407^{* * *} \\
(0.0039)\end{array}$ & Prob Mass for Pt 2 & $\begin{array}{l}0.4225^{* * *} \\
(0.0112)\end{array}$ \\
Support Point 3 & $\begin{array}{l}0.6799 * * * \\
\text { (0.0036) }\end{array}$ & Prob Mass for Pt 3 & $0.4799^{* * *}$ \\
Support Point 4 & 1.0000 & Prob Mass for Pt 4 & $0.0112)$ \\
\hline
\end{tabular}

Table 5D: Summary

\begin{tabular}{lccc}
\hline \hline \multirow{2}{*}{ Log of the Likelihood Function } & Model 1 & & Model 2 \\
\cline { 2 - 2 } Number of Cases & $-74,067$ & & $-68,842$ \\
Number of estimates parameters & 3,507 & & 3,507 \\
\hline
\end{tabular}

Notes: Detailed description of the variables are in Table Apeendix B. 
Table 6: Simulated Effects of Marriage Promotion and Added Education on Marital Status and Wage Rates

Simulation 1: Raise the Utility of Marriage at Age 25

\begin{tabular}{|c|c|c|c|c|c|c|c|c|c|c|}
\hline \multirow[b]{2}{*}{ Age } & \multicolumn{2}{|c|}{ Never-Married } & \multicolumn{2}{|c|}{ Married } & \multicolumn{2}{|c|}{ Divorced } & \multicolumn{2}{|c|}{ Job Change } & \multicolumn{2}{|c|}{ Ln Wage } \\
\hline & Base & Difference & Base & Difference & Base & Difference & Base & Difference & Base & Difference \\
\hline 25 & $56.5 \%$ & $-7.2 \%$ & $36.8 \%$ & $7.2 \%$ & $6.7 \%$ & $0.0 \%$ & $39.8 \%$ & $-0.38 \%$ & 1.797 & $0.52 \%$ \\
\hline 26 & $50.8 \%$ & $-6.3 \%$ & $41.3 \%$ & $5.7 \%$ & $7.9 \%$ & $0.6 \%$ & $37.7 \%$ & $-0.24 \%$ & 1.838 & $0.75 \%$ \\
\hline 27 & $46.7 \%$ & $-5.6 \%$ & $44.4 \%$ & $4.4 \%$ & $8.9 \%$ & $1.2 \%$ & $36.7 \%$ & $-0.30 \%$ & 1.872 & $0.65 \%$ \\
\hline 28 & $43.1 \%$ & $-4.7 \%$ & $46.7 \%$ & $3.6 \%$ & $10.1 \%$ & $1.1 \%$ & $33.8 \%$ & $-0.59 \%$ & 1.902 & $0.61 \%$ \\
\hline 29 & $40.7 \%$ & $-4.2 \%$ & $48.3 \%$ & $3.0 \%$ & $11.0 \%$ & $1.2 \%$ & $33.3 \%$ & $-0.35 \%$ & 1.930 & $0.55 \%$ \\
\hline 30 & $38.4 \%$ & $-3.9 \%$ & $49.1 \%$ & $3.0 \%$ & $12.6 \%$ & $1.0 \%$ & $33.1 \%$ & $0.00 \%$ & 1.940 & $0.54 \%$ \\
\hline 31 & $36.6 \%$ & $-3.3 \%$ & $50.1 \%$ & $2.4 \%$ & $13.3 \%$ & $0.9 \%$ & $32.0 \%$ & $0.09 \%$ & 1.962 & $0.43 \%$ \\
\hline $29-31$ & $38.6 \%$ & $-3.8 \%$ & $49.1 \%$ & $2.8 \%$ & $12.3 \%$ & $1.0 \%$ & $32.8 \%$ & $-0.13 \%$ & 1.944 & $0.51 \%$ \\
\hline \multicolumn{11}{|c|}{ Wage gains to the men affected by the simulation: } \\
\hline \multicolumn{8}{|c|}{ Averaged Among Added 25 Year-Old Married Men } & \multicolumn{3}{|l|}{$7.34 \%$} \\
\hline \multicolumn{8}{|c|}{ Gain at 29-31 Averaged Over Men Induced to Marry at Age 25} & \multicolumn{3}{|l|}{$7.06 \%$} \\
\hline \multicolumn{8}{|c|}{ Pure Marital Status Effect on Men Induced to Marry at Age 25} & \multicolumn{3}{|l|}{$4.83 \%$} \\
\hline \multicolumn{8}{|c|}{ Feedback Effect of Marital Status, Job Stability, and Wages } & \multicolumn{3}{|l|}{$2.23 \%$} \\
\hline
\end{tabular}

Simulation 2: Lower the Utility of Divorce at Age 25

\begin{tabular}{|c|c|c|c|c|c|c|c|c|c|c|}
\hline \multirow[b]{2}{*}{ Age } & \multicolumn{2}{|c|}{ Never-Married } & \multicolumn{2}{|c|}{ Married } & \multicolumn{2}{|c|}{ Divorced } & \multicolumn{2}{|c|}{ Job Change } & \multicolumn{2}{|c|}{ Ln Wage } \\
\hline & Base & Difference & Base & Difference & Base & Difference & Base & Difference & Base & Difference \\
\hline 25 & $56.5 \%$ & $0.0 \%$ & $36.8 \%$ & $2.1 \%$ & $6.7 \%$ & $-2.1 \%$ & $39.8 \%$ & $-0.06 \%$ & 1.797 & $0.16 \%$ \\
\hline 26 & $50.8 \%$ & $0.0 \%$ & $41.3 \%$ & $1.5 \%$ & $7.9 \%$ & $-1.5 \%$ & $37.7 \%$ & $-0.30 \%$ & 1.838 & $0.16 \%$ \\
\hline 27 & $46.7 \%$ & $0.0 \%$ & $44.4 \%$ & $1.3 \%$ & $8.9 \%$ & $-1.2 \%$ & $36.7 \%$ & $-0.36 \%$ & 1.872 & $0.16 \%$ \\
\hline 28 & $43.1 \%$ & $0.0 \%$ & $46.7 \%$ & $1.1 \%$ & $10.1 \%$ & $-1.0 \%$ & $33.8 \%$ & $-0.35 \%$ & 1.902 & $0.16 \%$ \\
\hline $27-28$ & $44.9 \%$ & $0.0 \%$ & $45.6 \%$ & $1.2 \%$ & $9.5 \%$ & $-1.1 \%$ & $35.3 \%$ & $-0.36 \%$ & 1.887 & $0.16 \%$ \\
\hline \multicolumn{11}{|c|}{ Wage gains to the men affected by the simulation: } \\
\hline \multicolumn{7}{|c|}{ Gain at 26-28 Averaged Over Men Induced Not to Divorce at Age 25} & \multicolumn{2}{|r|}{$7.58 \%$} & & \\
\hline \multicolumn{7}{|c|}{ Pure Marital Status Effect at 26-28 on Men Induced Not to Divorce at Age 25} & \multicolumn{2}{|r|}{$4.98 \%$} & & \\
\hline \multicolumn{7}{|c|}{ Feedback Effect of Marital Status, Job Stability, and Wages } & \multicolumn{2}{|r|}{$2.60 \%$} & & \\
\hline
\end{tabular}

Simulation 3: Raise Years of Schooling by One Year For All Ages

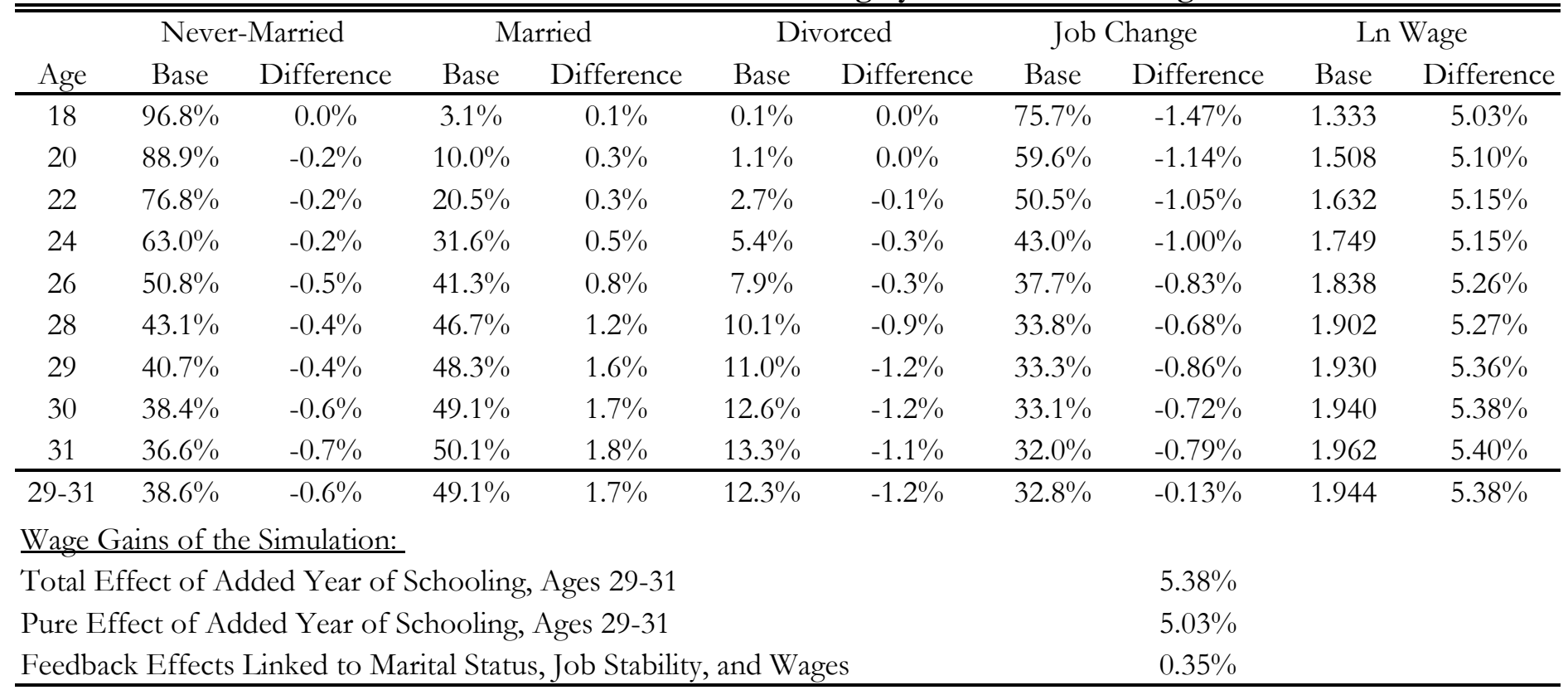




\section{Appendix Table A: Reasons Indicates Jobs' Separation by Represented Groups}

Panel A: By Age, Race and Ethnic Groups

\begin{tabular}{lcccccc} 
Reasons for Jobs' & & Age & Age & & & \\
Separation & All & $20-23$ & $28-31$ & Hispanic & Black & White \\
\hline Layoff & 17.3 & 21.4 & 13.4 & 19.9 & 16.8 & 16.8 \\
Fired & 12.9 & 13.1 & 14.9 & 12.5 & 15.3 & 11.3 \\
Program End & 4.5 & 6.1 & 1.7 & 3.0 & 6.9 & 3.3 \\
Quit because of Family & 0.7 & 0.5 & 1.0 & 0.7 & 0.9 & 0.6 \\
Quit because of Other & 33.7 & 37.5 & 31.2 & 31.9 & 35.3 & 33.3 \\
Missing or no reason & 30.9 & 21.4 & 37.8 & 32.1 & 24.8 & 34.9 \\
& & & & & & \\
Number of Obs. & 25,858 & 8,346 & 5,122 & 4,893 & 9,120 & 11,845 \\
\hline
\end{tabular}

Panel B: By Education and family Status Groups

\begin{tabular}{lcccccc}
\hline \hline Reasons for Jobs' & Less than & \multicolumn{5}{c}{ BA and } \\
Separation & HS & HS & more & Single & Married & Divorced \\
\hline Layoff & 19.8 & 18.1 & 7.0 & 18.1 & 15.4 & 16.0 \\
Fired & 13.5 & 12.0 & 15.1 & 13.0 & 11.9 & 16.4 \\
Program End & 4.8 & 4.0 & 4.3 & 5.2 & 3.1 & 2.2 \\
Quit because of Family & 0.8 & 0.6 & 0.3 & 0.6 & 1.1 & 1.1 \\
Quit because of Other & 29.0 & 34.1 & 36.7 & 34.4 & 31.1 & 35.4 \\
Missing or no reason & 32.1 & 31.1 & 36.7 & 28.8 & 37.4 & 28.9 \\
& & & & & & \\
Number of Obs. & 8,080 & 11,152 & 1,929 & 18,683 & 4,946 & 1,697 \\
\hline
\end{tabular}

Notes: The table is based on the question: "which of the reasons on this card best describes why you happened to leave this job"? (1) lay off; (2) discharged or fired; (3) end of temporary/seasonal job or program ended; (4) quit for pregnancy/family reasons; and (5) quit for other reasons. 
Variable Name

\section{DEPENDENT AND ENDOGENOUS VARIABLES}

Marital Status

Change job from Last Year

Ln of Hourly Wage Rate
Marital status of R: single, new marriage, cont. marriage, new divorce, cont. divorce, new remarriage

Dummy variable indicating whether $\mathrm{R}$ change job during the last year

Ln of Hourly Wage Rate
3

NA

4

0.471

5

\section{SELECTED INDEPENDENT VARIABLES}

\section{Ascribed Traits and Scholastic Aptitude (X)}

Age

Black

Hispanic

Foreign

AFQT

\section{Family Background (X)}

Family Income

Total annual family income in $1979(\$ 1,000,000)$

Mother's Education

Number of Siblings

Female-Headed Household
Age at the beginning of the year

Dummy variable indicating African American

Dummy variable indicating Hispanic

Dummy variable indicating Foreign born

Armed Forces Qualify Test score

(Age and scale adjusted to 1,10 interval)
Number of living siblings in 1979
$3,4,5 \quad 24.25$

$3,4,5 \quad 0.304$

$3,4,5 \quad 0.193$

$5 \quad 0.070$

$3,4,5 \quad 3.045$

$3,4,5 \quad 0.019$

$3,4,5 \quad 10.97$

$3 \quad 3.809$

Dummy, $\mathrm{R}$ lived in a female-headed household at age 14

3

0.185

\section{Work Experience and Education Indicators (Z)}

Work Experience

Military Experience

Number of Jobs

Job change prior year

Ln earnings prior year

Highest grade completed

In School

In School prior year

GED
Weeks (divided by 52) worked from age 17 to this year

Total Years of Military Experience

Total number of jobs ever reported

Dummy, indicating whether $\mathrm{R}$ change job during prior year

Lag of the wage rate from prior year

Highest grade comp. through the beginning of this year

Attending school at the Interview date

Attending school at last year Interview date

Received GED
$3,4,5$

4.913

$4,5 \quad 0.662$

$3,4,5 \quad 6.353$

$3,5 \quad 0.506$

$3,4 \quad 1.668$

$3,4,5 \quad 12.27$

$5 \quad 0.244$

$4 \quad 0.236$

5

0.084 


\section{Marital and Family Statuses (MS)}

Years Married

New Marriage

Continuing Marriage

New Divorce or Separation

Continuing Divorce or Separation

New Remarriage

One or Two Child

Three or more children

\section{Social Affiliation (X)}

Baptists Religion

Catholic Religion

Frequency of Church Att
Years since started current Marriage

Those who continue to be married in the current year (including second marriages)

Those who divorced or separated during this year

Those who continue to be divorced or separated during the current year

Those who remarried during this calendar year

has one or two children at the beginning of this year

has three or more children at the beginning of this year
4,5

4,5

4,5

1.345

0.047

0.251

$4,5 \quad 0.018$

$\begin{array}{ll}4,5 & 0.049\end{array}$

$4,5 \quad 0.008$

$4,5 \quad 0.287$

$4,5 \quad 0.059$

$3 \quad 0.288$

$3 \quad 0.343$

$3 \quad 3.220$

\section{Local Market Conditions (X)}

Resident in Urban area

County Average Earnings

County Empl. Growth

County Unempl. Rate

County Divorce Rate
R. is presently resident in Urban area

$3,4,5$

0.816

Average earnings per job in R's county of residence $(\$ 1,000)$

3,5

Percent employment growth in R's county of residence

4,5

4,5

Unemployment Rate in R's county of residence

Divorces rates per 1,000 in R's County of residence
15.40

0.026

7.574

$3 \quad 4.957$ 
Appendix Table C: Effects of Changes in the Value of Marriage at Age 25 on Job Stability and Wage Rates

\begin{tabular}{|c|c|c|c|c|c|c|c|c|c|c|c|c|c|c|c|}
\hline \multicolumn{4}{|c|}{ Single } & \multicolumn{3}{|c|}{ Married } & \multicolumn{3}{|c|}{ Divorced } & \multicolumn{3}{|c|}{ Job Change } & \multicolumn{3}{|c|}{ Ln Wage } \\
\hline Age & base & Sim. 1 & Diff. & base & Sim. 1 & Diff. & base & Sim. 1 & Diff. & base & Sim. 1 & Diff. & base & Sim. 1 & Diff. \\
\hline 17 & $98.6 \%$ & $98.6 \%$ & $0.0 \%$ & $1.4 \%$ & $1.4 \%$ & $0.0 \%$ & $0.0 \%$ & $0.0 \%$ & $0.0 \%$ & $78.8 \%$ & $78.8 \%$ & $0.00 \%$ & 1.313 & 1.313 & $0.00 \%$ \\
\hline 18 & $96.8 \%$ & $96.8 \%$ & $0.0 \%$ & $3.1 \%$ & $3.1 \%$ & $0.0 \%$ & $0.1 \%$ & $0.1 \%$ & $0.0 \%$ & $75.7 \%$ & $75.7 \%$ & $0.00 \%$ & 1.333 & 1.333 & $0.00 \%$ \\
\hline 19 & $93.7 \%$ & $93.7 \%$ & $0.0 \%$ & $5.8 \%$ & $5.8 \%$ & $0.0 \%$ & $0.4 \%$ & $0.4 \%$ & $0.0 \%$ & $66.1 \%$ & $66.1 \%$ & $0.00 \%$ & 1.425 & 1.425 & $0.00 \%$ \\
\hline 20 & $88.9 \%$ & $88.9 \%$ & $0.0 \%$ & $10.0 \%$ & $10.0 \%$ & $0.0 \%$ & $1.1 \%$ & $1.1 \%$ & $0.0 \%$ & $59.6 \%$ & $59.6 \%$ & $0.00 \%$ & 1.508 & 1.508 & $0.00 \%$ \\
\hline 21 & $82.8 \%$ & $82.8 \%$ & $0.0 \%$ & $15.5 \%$ & $15.5 \%$ & $0.0 \%$ & $1.6 \%$ & $1.6 \%$ & $0.0 \%$ & $53.7 \%$ & $53.7 \%$ & $0.00 \%$ & 1.572 & 1.572 & $0.00 \%$ \\
\hline 22 & $76.8 \%$ & $76.8 \%$ & $0.0 \%$ & $20.5 \%$ & $20.5 \%$ & $0.0 \%$ & $2.7 \%$ & $2.7 \%$ & $0.0 \%$ & $50.5 \%$ & $50.5 \%$ & $0.00 \%$ & 1.632 & 1.632 & $0.00 \%$ \\
\hline 23 & $69.6 \%$ & $69.6 \%$ & $0.0 \%$ & $26.8 \%$ & $26.8 \%$ & $0.0 \%$ & $3.7 \%$ & $3.7 \%$ & $0.0 \%$ & $45.6 \%$ & $45.6 \%$ & $0.00 \%$ & 1.693 & 1.693 & $0.00 \%$ \\
\hline 24 & $63.0 \%$ & $63.0 \%$ & $0.0 \%$ & $31.6 \%$ & $31.6 \%$ & $0.0 \%$ & $5.4 \%$ & $5.4 \%$ & $0.0 \%$ & $43.0 \%$ & $43.0 \%$ & $0.00 \%$ & 1.749 & 1.749 & $0.00 \%$ \\
\hline 25 & $56.5 \%$ & $49.3 \%$ & $-7.2 \%$ & $36.8 \%$ & $43.9 \%$ & $7.2 \%$ & $6.7 \%$ & $6.7 \%$ & $0.0 \%$ & $39.8 \%$ & $39.4 \%$ & $-0.38 \%$ & 1.797 & 1.802 & $0.52 \%$ \\
\hline 26 & $50.8 \%$ & $44.5 \%$ & $-6.3 \%$ & $41.3 \%$ & $47.0 \%$ & $5.7 \%$ & $7.9 \%$ & $8.5 \%$ & $0.6 \%$ & $37.7 \%$ & $37.4 \%$ & $-0.24 \%$ & 1.838 & 1.846 & $0.75 \%$ \\
\hline 27 & $46.7 \%$ & $41.1 \%$ & $-5.6 \%$ & $44.4 \%$ & $48.8 \%$ & $4.4 \%$ & $8.9 \%$ & $10.1 \%$ & $1.2 \%$ & $36.7 \%$ & $36.4 \%$ & $-0.30 \%$ & 1.872 & 1.878 & $0.65 \%$ \\
\hline 28 & $43.1 \%$ & $38.4 \%$ & $-4.7 \%$ & $46.7 \%$ & $50.3 \%$ & $3.6 \%$ & $10.1 \%$ & $11.3 \%$ & $1.1 \%$ & $33.8 \%$ & $33.2 \%$ & $-0.59 \%$ & 1.902 & 1.908 & $0.61 \%$ \\
\hline 29 & $40.7 \%$ & $36.5 \%$ & $-4.2 \%$ & $48.3 \%$ & $51.2 \%$ & $3.0 \%$ & $11.0 \%$ & $12.3 \%$ & $1.2 \%$ & $33.3 \%$ & $32.9 \%$ & $-0.35 \%$ & 1.930 & 1.935 & $0.55 \%$ \\
\hline 30 & $38.4 \%$ & $34.5 \%$ & $-3.9 \%$ & $49.1 \%$ & $52.0 \%$ & $3.0 \%$ & $12.6 \%$ & $13.5 \%$ & $1.0 \%$ & $33.1 \%$ & $33.1 \%$ & $0.00 \%$ & 1.940 & 1.946 & $0.54 \%$ \\
\hline 31 & $36.6 \%$ & $33.3 \%$ & $-3.3 \%$ & $50.1 \%$ & $52.5 \%$ & $2.4 \%$ & $13.3 \%$ & $14.2 \%$ & $0.9 \%$ & $32.0 \%$ & $32.1 \%$ & $0.09 \%$ & 1.962 & 1.967 & $0.43 \%$ \\
\hline 32 & $35.3 \%$ & $32.7 \%$ & $-2.6 \%$ & $51.7 \%$ & $53.6 \%$ & $1.9 \%$ & $13.0 \%$ & $13.7 \%$ & $0.7 \%$ & $32.1 \%$ & $32.0 \%$ & $-0.06 \%$ & 1.962 & 1.966 & $0.33 \%$ \\
\hline Average & $63.6 \%$ & $61.3 \%$ & $-2.4 \%$ & $30.2 \%$ & $32.1 \%$ & $1.9 \%$ & $6.2 \%$ & $6.6 \%$ & $0.4 \%$ & $47.0 \%$ & $46.9 \%$ & $-0.11 \%$ & 1.714 & 1.717 & $0.27 \%$ \\
\hline
\end{tabular}

